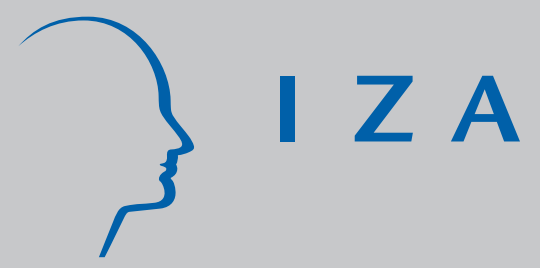

IZA DP No. 1234

Immigrant versus Native Businesswomen:

Proclivity and Performance

Amelie Constant

August 2004 


\title{
Immigrant versus Native Businesswomen: Proclivity and Performance
}

\author{
Amelie Constant
}

IZA Bonn

\section{Discussion Paper No. 1234 \\ August 2004}

\author{
IZA
}

P.O. Box 7240

53072 Bonn

Germany

Phone: +49-228-3894-0

Fax: +49-228-3894-180

Email: iza@iza.org

Any opinions expressed here are those of the author(s) and not those of the institute. Research disseminated by IZA may include views on policy, but the institute itself takes no institutional policy positions.

The Institute for the Study of Labor (IZA) in Bonn is a local and virtual international research center and a place of communication between science, politics and business. IZA is an independent nonprofit company supported by Deutsche Post World Net. The center is associated with the University of Bonn and offers a stimulating research environment through its research networks, research support, and visitors and doctoral programs. IZA engages in (i) original and internationally competitive research in all fields of labor economics, (ii) development of policy concepts, and (iii) dissemination of research results and concepts to the interested public.

IZA Discussion Papers often represent preliminary work and are circulated to encourage discussion. Citation of such a paper should account for its provisional character. A revised version may be available directly from the author. 


\section{ABSTRACT}

\section{Immigrant versus Native Businesswomen: Proclivity and Performance*}

Career positions in German economic life are still male-dominated, and the driving forces behind success are not yet well understood. This paper contributes to a better understanding by classifying success stories in self-employment and business careers, and by investigating differences between native women (both from West and East Germany) and migrants using a rich data set from the German Socio-economic Panel. Results on self-employment proclivity are very sensitive to the alternative choice. Women choose self-employment over a business career in the salaried sector when they are older, less educated, have under-age children, and parents who are self-employed themselves. When women are younger and more educated but have children, they choose self-employment as a way to circumvent unemployment. Women who are more educated and do not have under-age children are more likely to be businesswomen in the salaried sector, suggesting a clear choice for a secure job. East German women are less likely to choose self-employment or a business career than West German women. Overall, compared to other types of employment, selfemployment offers women the desirable and valuable element of time and space flexibility. Businesswomen in paid-employment earn the highest wages and this is long-lasting. Compared to women in lower dependent employment, those in self-employment earn more. Thus, self-employment offers women a path to economic success. Invariably, East German women earn less than West German women.

JEL Classification: J23, M13, J15, J16, J24, J61, J31

Keywords: entrepreneurship, self-employment, occupational choice, economics of minorities, economics of gender, immigrants

Amelie Constant

IZA

P.O. Box 7240

53072 Bonn

Germany

Tel.: +49-228-3894-301

Fax: +49-228-3894-180

Email: constant@iza.org

\footnotetext{
${ }^{*}$ I owe special thanks to Klaus F. Zimmermann for insightful suggestions and countless stimulating discussions on this paper. I am also thankful to Barry R. Chiswick and Sherrie Kossoudji for their helpful comments on earlier drafts. An earlier draft of this paper was presented at the Mid-West Economic Association Annual Meeting 2004 in Chicago. I thank Steve Woodbury and Don Williams for comments. Stephanie Wei Wang and Julia Papenkort provided excellent student assistance.
} 


\section{Introduction}

Business ownership and self-employment, as an effective form of entrepreneurship, may be a risky venture that requires hard work but it has an intrinsic appeal by offering individuals the sense of independence, satisfaction with the job, higher self-worth, and higher earnings. For a country, selfemployment is a beneficial sector as it contributes to job creation, economic growth, and alleviates the welfare burden. For women, in particular, self-employment can be a valuable option in the labor market because it can offer time flexibility in combining running a business with running a family. The added value of self-employment lies in the space flexibility. Women can run their business from their home or at a place close to their home. However, entrepreneurship can also manifest itself in the salaried sector. Many businessmen and businesswomen in companies around the world exhibit and apply their entrepreneurial talents every day. They identify niches, take initiatives, devise plans, make risky decisions, identify economic opportunities, face competition, characterize a company etc. while working for somebody else.

Research on self-employment entrepreneurship in Europe, and Germany in particular, lags behind research in the US. ${ }^{1}$ Recent papers in the rising literature on self-employment in Europe, the US, and other immigration countries include Taylor (1996, and 2001), Blanchflower, Oswald and Stutzer (2001), Audretsch (2002), Audretsch, Thurik, Verheul and Wennekers (2002), and Constant and Shachmurove (2003). While some of these studies offer excellent comparisons across counties, they mostly concentrate on males. They identify the role of managerial and other individual abilities, family background, occupational status, financial constraints, the nature of work, satisfaction and happiness with the job, personal autonomy, and ethnic enclaves, among other factors as relevant determinants of self-employment. In general, self-employment is viewed as a

\footnotetext{
${ }^{1}$ For an excellent survey see Le (1999).
} 
positive choice and as a means to be creative and rewarded in the labor market.

Self-employment is male dominated in most countries. With the exception of Vietnamese women, Fairlie and Meyer (1996) document lower self-employment rates for women in the US in 1990. In Germany, research on immigrant and female entrepreneurship, in particular, is at the very early stages. One reason is that the low labor force participation of women and their even lower self-employment rates result in few observations to justify empirical analyses. The traditional breadwinner or gender-role model that governs German families, the institutional settings, and the welfare state provisions are often cited as the culprits for the low rates of female self-employment.

Among the few recent studies on gender differences in self-employment in Germany (both in economics and sociology), some concentrate on self-employment determinants (Fehrenbach and Lauxen-Ulbrich, 2002; Lohmann, 2001; McManus, 2001; and Jungbauer-Gans and Preisendörfer, 1992) and some on determinants and earnings (Georgellis and Wall, 2000). Emphasizing differences between full- and part-time work, Lohmann (2001) investigates male and female selfemployment determinants in Germany, Italy, France, Sweden, the UK, and the US. His results verify that self-employment offers women more flexibility to combine family with work and that different institutional settings create differing opportunities, leading to different outcomes for selfemployment. Observed gender differences are more pronounced across countries than within countries.

McManus (2001) finds prominent gender differences and persistence of gendered pathways into self-employment. She states that while women with young children are more likely to go into self-employment, the major determinant is spousal transmission (that is, when the husband is selfemployed). Looking at men and women who are already self-employed, Jungbauer-Gans and Preisendörfer (1992) find considerable sex segregation. Self-employed women have lower human capital and experience, have lower survival rates and are disproportionately found in trades, 
services, and in typically female occupations. However, when they control for human capital and business characteristics, these gender differences in self-employment disappear and women experience the same survival and success as men. Hükum and Le Saout (2002) find that self-employed immigrant women in France are capable of transferring their professional know-how into a variety of economic activity. Characterized by an entrepreneurial ethos, these women show a superior ability to mobilize their social, ethnic, and personal resources in order to succeed in an often-fragile labour market. For these immigrant women, becoming self-employed is a way of achieving a respectable social status even though it does not necessarily mean that they achieve high earnings.

All studies agree that the motives to choose self-employment are different for men and women, with women emphasizing domestic responsibilities and men stressing the value of a successful employment option. Self-employed women are well-educated (in some studies) indicating that self-employment choices are due to familial reasons rather than discrimination or inability to find another job (Georgellis and Wall, 2000). However, compared to men, women face additional constraints from lack of start-up capital to convincing the financial institutions (and even their potential clientele) about their business ideas and managerial abilities (OECD, 2000).

Research on the self-employment experience of immigrants in the US shows that not only self-employed immigrants have higher annual incomes than salaried workers but they also have higher incomes than comparable self-employed natives (Borjas, 1986). Self-employment rates also widely vary by ethnicity. Fairlie and Meyer (1996), in a comprehensive study of ethnic/racial groups by gender, test many theories and find evidence that individuals are pulled rather than pushed into self-employment. Lofstrom (2002) finds substantial differences between migrant workers and self-employed migrants in earnings and educational attainment. Entrepreneurs have a better education and earn more than other working migrants. However, education has a smaller 
impact on the self-employment probabilities of migrants compared to that of natives. The earnings of self-employed immigrants converge quickly to the earnings of the self-employed natives. In contrast, Clark and Drinkwater (1998) in their study on ethnic self-employment in Britain find evidence of both push and pull factors, with substantial variation across ethnic groups. Furthermore, they find no support of the conjecture that ethnic minorities are more entrepreneurial than others. Except for the Chinese, they find that ethnic self-employed minorities in Britain earn less than comparable whites.

Germany is known to have comparatively low rates of self-employment and migrants exhibit even lower rates. This is in spite of the fact that the self-employed immigrants reach earnings parity with self-employed natives and earn a premium of $30 \%$ over immigrant workers in the blue collar category (Constant, 1998). Compared to all immigrants in the salaried sector, self-employed immigrants earn 22\% more, and Turks are twice as likely to become self-employed as any other immigrant group (Constant, Shachmurove, and Zimmermann (2003).

A recent comparative study between Germany and Denmark shows that the selfemployment of immigrants is male dominated and self-employed immigrants in Germany earn twice as much as the immigrants in paid employment (Constant and Schultz-Nielsen, 2004). Focusing on immigrants in the labor force, they find significant gender and ethnic differences, with women being three times less likely than men to become self-employed. It is unclear why, in a country with a relative high unemployment rate and a relatively institutionalized labor market entry, one does not observe higher self-employment activities among immigrants, especially when most of the immigrants come from countries with high self-employment rates (24\% in Greece, $25 \%$ in Turkey, $27 \%$ in Italy, etc). ${ }^{2}$

\footnotetext{
${ }^{2}$ Fairlie and Meyer (1996), however, find that the ethnic/racial groups that have the highest selfemployment rates do not come form countries that have high self-employment rates.
} 
In this paper I investigate female entrepreneurship evidenced through both self- and paidemployment, presenting a new perspective on entrepreneurship. Specifically, I study the sorting of businesswomen into self- or paid-employment and contrast it to the sorting of women into other jobs in the salaried sector. To emphasize differences, I compare these female workers to the women not in the labor force. Moreover, I estimate the wages of women in these types of employment, adjusted for selection in each type of employment. I address the following questions: (i) what does it take to become a businesswoman? Are businesswomen in self-employment different from businesswomen in paid-employment in observed characteristics? (ii) is self-employment an unequivocal choice over other jobs in the wage sector? Is it a preferred route to express their entrepreneurial talents and a quest to earn higher wages, or a conduit to avoid possible discrimination in the wage sector, and to combine family with work in a more flexible setting? (iii) is self-employment a desperate choice out of unemployment or idleness? (iv) within the unified Germany are some nationalities more entrepreneurial than others?(v) are female workers in these 3 types of employment a random sample? And (vi) how do they fare in the German labor market?

For the empirical analyses, I employ data from the German Socioeconomic Panel (GSOEP) 2000 release to study the factors that influence the choice to work or not to work, and the choice to be self-employed or not, in a multinomial logit framework. I utilize this selection into different occupations to further adjust and study the wages of women workers. The results show differences among West Germans, East Germans, and immigrants both in their decision to become selfemployed businesswomen and in their decision to become businesswomen in paid-employment. Proclivity to self-employment is very sensitive to the alternative option (whether contrasted to other jobs in the salaried sector or to no employment). While self-employed businesswomen enjoy higher wages than in other paid jobs, self-employment is still not their preferred choice when they are young and well educated. Women are drawn into self-employment as opposed to another type of 
employment when they have under-age children, indicating the importance of familial considerations. Self-employment offers women a path to economic success. However, it is the businesswomen in the salaried sector who enjoy the highest wages, and this is long-lasting. Invariably, East German women earn less than West German women in all 3 types of employment.

The rest of the paper is structured in the following way: in Section II, I provide a brief overview of the self-employment realities in Germany, the German migration setting, and the situation for female entrepreneurs; in Section III, I present the methodology and empirical design, and in Section IV, I describe the data set, the variables employed in the analyses, and delineate the hypotheses. In Section V, I stage the characteristics of the sample populations, and in Section VI, I present and discuss the econometric results. In Section VII I summarize and draw my concluding remarks.

\section{Self-employment Realities in Germany}

In general, compared to both the US and to other countries that are less industrialized, Germany is characterized by low entrepreneurial activities (OECD, 2000). However, in 2000, the self-employed workers accounted for $9.8 \%$ of the total labor force $12.6 \%$ of whom were men and $6.2 \%$ women. Among the German self-employed, $27.10 \%$ are in the knowledge intensive services. Overall, close to 3 million small or mid-size enterprises (SMEs) in the crafts, industry, trade, tourism, service, and liberal professions create nearly $70 \%$ of jobs, and account for $46 \%$ of gross investment in Germany.

The self-employment structure of the immigrants in Germany has changed significantly since the mid-1970s, when almost all guestworkers were in paid-employment. For example, in the early1970s, only 40.000 immigrants were registered as self-employed, and their businesses were tied to restaurants or to catering to the needs of their compatriots. Since then more and more 
foreigners have become self-employed. Since the mid-1980s the number of start-ups by foreigners has increased rapidly. In April 2001, already 257,000 out of the 3.1 million or $8.4 \%$ of foreigners in the workforce were self-employed. Over the last decade, more foreigners went into self-employment compared to Germans. For example, the stock of self-employed foreigners alone rose by $23.6 \%$ between 1992 and 2001, while the rise of native self-employment was 17\% (Source: Mikrozensus). The Institut für Mittelstandsforschung in Mannheim reports that the share of self-employed immigrants in 2001 was $16 \%$ for Turks and Italians and 9\% for Greeks. While the overwhelming majority of Greeks and Italians are in the restaurant and hotel business, the majority of Turks are in the wholesale/retail business.

While female-owned enterprises are considered to be the "new face of the economy" in the US, and financial institutions increasingly patronize women as a substantial clientele, this is not the case in Germany (OECD, 2000). Compared to men, women bear the brunt of family responsibilities, lack labor market experience, have less collateral to start-up a business, and are usually confined in very small businesses. In 1998, recognizing that women are broadly underrepresented in SME's, and that lack of start-up capital is a major obstacle for businesswomen, the German government enacted a special funding scheme for start-ups of WOBs (OECD, 2000).

The institutional and legal conditions for foreigners planning to become self-employed have improved over the last decades. The Foreigner's Law of 1965 explicitly prohibited immigrants from engaging in business endeavors (Kanein, 1988). An exception applied to EU nationals and immigrants with an unlimited residence permit. A minimum of 5 years residence in Germany (but in practice 8 years) is required to obtain this permit. Apart from this legislation, there is no explicit law regulating the self-employment of foreigners. Currently, immigrants from EU countries ${ }^{3}$ have

\footnotetext{
${ }^{3}$ Iceland, Liechtenstein, and Norway also enjoy the same rights; the US, Philippines, Sri Lanka, and Dominican Republic enjoy a benevolent treatment.
} 
basically the same legal rights as German entrepreneurs. Immigrants from non-EU countries are subject to the Ausländergesetz and must have an unlimited residence permit or apply for the permission to start a business if they only have a limited residence permit. In practice, the approval of such applications has been liberalized over the last years but is still occasionally arbitrary.

The new Immigration Act (Zuwanderungsgesetz), which will come into effect on January 1, 2005 allows, inter alia, non-European nationals to immigrate to Germany for work and settle permanently if they so desire. It favors highly skilled workers, such as scientists, engineers, and IT specialists, who are urgently needed in Germany's labor market. Exploring immigration as a potential economic boon, this law allows entrepreneurs who invest at least a million Euros and offer jobs to locals to work in Germany. While the new law also carries through tough security provisions, it liberalizes the citizenship laws and speeds up the process of becoming German. The law mandates that new long term immigrants complete 300 hours of courses on language as well as civil and societal issues, while those already settled in Germany also take part in integration courses. Completing these courses successfully entitles immigrants to naturalization after seven years of residence in Germany.

Because of the idiosyncrasies of the German migration system and the German immigration law, the typical distinction between first and second generation immigrants does not apply in Germany. Second or even third generation immigrants who are born in Germany are not necessarily German citizens. ${ }^{4}$ Even if they acquire German citizenship, they are perceived as foreigners and follow separate paths in the labor market. On the other hand, the immigrants themselves may be reluctant to ascend to German citizenship in fear of losing their own, as well as losing property and

\footnotetext{
${ }^{4}$ As of January 1,2000 , the citizenship law requires a minimum of 8 years of residence. In addition to the jus sanguinis or law of blood the jus soli or law of soil qualifies immigrant children for German citizenship if one parent is born in Germany or has established permanent residence status in Germany. At the age of 23 descendants must decide which nationality to keep because dual citizenship is not allowed.
} 
other benefits in their home country (Constant, 1998).

In general, doctors, lawyers, accountants, engineers, pharmacists, midwives etc. need an occupational licence to open their own business. Specific occupational credentials and certificates are required for other professions as well. Individuals who are considering starting a business in trade or craft also need to have some educational degree or occupational certificate (master craftsman). This applies especially to cooks, carpenters, hairdressers, etc. Although the reformed legislation for the trade/craft professions has been more liberal since January 1, 2004, 41 of the 94 types of craft can only be practiced with a master craftsmen diploma.

Within Germany, many individual states and cities are seriously taking actions to promote self-employment. In the city of Berlin, for example, the "Consulting Centre for Self-Employment" (funded by the German Government) caters to the needs of immigrants and especially Turks. Among other things, it provides training in accounting and marketing, advises on business opportunities in Berlin, and enhances cooperation between business associations (IOM, 2003). The federal government itself actively seeks to encourage, foster and strengthen the performance and competitiveness of SMEs and offer them new growth possibilities. In June 2002, the German government began to assist the development of a private risk capital market in Germany by making available considerable amounts of venture capital for young technology companies especially via the VTC - Venture Capital for Small Technology Companies.

Special schemes to push individuals out of unemployment and into self-employment are also in effect. The bridging allowance (Überbrückungsgeld) is a combination, among other things, of financial support through monthly unemployment benefits and social security contributions. The help period lasts for 6 months. The premium allowance $(I c h-A G)$ supports individuals for 3 years starting with high premium payments in the first year (600Euros a month). Payments decrease to 360 and 240Euros a month for the second and third year respectively. 
A variety of social, cultural, political and economic impediments can discourage or even suppress entrepreneurial endeavors. For immigrants and women these obstacles (such as the ability to raise or secure capital, to acquire managerial talents, and to capture market opportunities) may be greater. One of the most important hurdles is credit constraint or limited financial capital for start-up business. The largest fraction of newly founded businesses in Germany are financed by the entrepreneur's own capital in combination with outside capital provided by credit institutions. Venture capital and private investors (business angels) play a role only in a few cases. In the case of immigrants, family and friends are usually the business angels. Another hurdle is the lack of knowledge about the support programs that are available to encourage and promote self-employment, or about the existing consulting centers.

Still, even if immigrants are informed about business opportunities and encouraged to open their own business, the next hurdle to overcome is regulations and bureaucracy. Experts believe that there are too many regulations that hinder entrepreneurial activities, and advocate against unreasonable paperwork. Furthermore, the complicated German tax system can also deter many potential business founders. In recent years, many changes have been made to the tax laws, often making it impossible for businesses to understand the system.

Another impediment to self-employment is the alleged German "welfare culture." This culture has at least two dimensions. On the one hand, less privileged workers need to be protected from unemployment or precarious, risky employment. Therefore, the German labor market directive has focused on paid-employment rather than self-employment. At the same time, labor unions have also encouraged paid-employment perhaps because independent trades are not exactly under their umbrella. On the other hand, a tacit directive (that emphasizes the collective) deters individuals from choosing the entrepreneurial avenue and acquiring high profits.

In an effort to evoke a "self-employment culture" in Germany and to ensure successful 
transmission of business ownership to the younger generations, the Federal Ministry of Economics and Technology initiated professorships on self-employment. Special attention is paid to technology-oriented companies originating in Universities and to school projects that can strengthen young peoples sense of self-reliance, initiative-taking, and team spirit (OECD, 2000).

\section{Methodology and Empirical Implementation}

In the methodological framework, the unit of the analysis is the individual. I assume a utility maximization model where rational individuals are assumed to have preferences over a set of $j$ different alternatives:

$$
\begin{aligned}
& U(\text { alternative } 0)=\beta_{0}^{\prime} x_{0}+\epsilon_{0} \\
& U(\text { alternative } 1)=\beta_{1}^{\prime} x_{1}+\epsilon_{1} \\
& U(\text { alternative } J)=\beta_{j}^{\prime} x_{j}+\epsilon_{j}
\end{aligned}
$$

where $\epsilon$ is the random error associated with that choice. $Y$ is observed for choice $j$ if

$$
U(\text { alternative } j)>U(\text { alternative } k) \quad \forall j \neq k
$$

The disturbances are assumed to be independently ${ }^{5}$ and identically distributed as a log Weibull distribution. Then, the choice probabilities given the covariates are:

$$
P\left(Y_{i}=j \mid x\right)=\frac{e^{\beta_{j}^{\prime} x_{j i}}}{\sum_{k=0}^{J} e^{\beta_{k}^{\prime} x_{k i}}}
$$

where $i$ indexes the individuals, and $j$ and $k$ index the alternative occupational choices, $j=0,1, \ldots$, J with $j+1$ nominal, unordered outcomes. To identify the parameters of the model, I impose the

\footnotetext{
${ }^{5}$ The Independence of Irrelevant Alternatives (IIA) is a restrictive assumption. McFadden (1973) suggested that in cases where the outcome categories "can plausibly be assumed to be distinct and weighed independently in the eyes of each decision maker," a multinomial logit model can be safely used.
} 
normalization $\beta_{0}=0$.

Specifically for this analysis of occupational choice $Y$ indicates occupations. I model the choice behavior of women as a multinomial logit. In this setting, individual agents face the following distinct choices: (i) the probability to choose to be a self-employed businesswoman, (ii) the probability to choose a career as a businesswoman in the salaried sector, (iii) the probability to choose any other type of job in the salaried sector, and (iv) the probability to choose not to work. Individual agents maximize utility gained from the attributes of that choice. I assume that utility depends on the corresponding financial rewards of the choice. For example, if the expected wages from self-employment exceed the expected wages from other types of employment, the individual workers choose to become self-employed.

I can predict the probability that an individual will choose one of the 4 occupations considered. According to the human capital theory, individuals will most likely choose the occupation that offers the highest present discounted value of potential future earnings. The probabilities (given the characteristics) are, therefore,

$$
P(Y=j \mid x)=\frac{e^{\beta_{j}^{\prime} x_{i}}}{1+\sum_{k=0}^{4} e^{\beta_{k}^{\prime} x_{i}}}
$$

The log-odds ratios that an individual will choose occupation $j$ over occupation $k$ are given by:

$$
\ln \left[\frac{P_{j}}{P_{k}}\right]=x_{i}\left(\beta_{j}-\beta_{k}\right)
$$

and the odds ratio, $P_{j} / P_{k}$, does not depend on the other choices. I compute the rest of the "contrasts" by taking the difference between two of the known parameters as follows: 


$$
\beta_{k, p \mid q}=\beta_{k, p \mid r}-\beta_{k, q \mid r}
$$

where outcome $\mathrm{r}$ is the reference category. That is, I compare outcomes $p$ versus $q$ for attribute $k$.

The model is solved with maximum likelihood estimation. The resulting estimates are unbiased, consistent, asymptotically normal, and asymptotically efficient. Moreover, the likelihood function is globally concave, ensuring the uniqueness of the ML estimates (Amemiya, 1985). The marginal effects are computed as:

$$
\frac{\theta P_{j}}{\theta x_{i}}=P_{j}\left[\beta_{j}-\bar{\beta}\right)
$$

where $\bar{\beta}=\sum_{j=0}^{J} P_{j} \beta_{j}$.

Women workers (and in particular) women working in the 3 types of employment considered in the multinomial logit may not be a random sample of the female population, I need to appropriately adjust their wages for selection. This estimation is more involving because of the use of the multinomial logit. However, Lee (1983) has devised a method to estimate wages. Following Lee, I proceed with the estimation of three wage regressions adjusted for selection; this selection is based on the e multinomial logit employment choices. The selection for the regressions is based on $Y_{i}=j$. The Mincerian type of log earnings equations is:

$$
\ln w_{i j}=\alpha^{\prime} z_{i}+\left(\rho_{j} \sigma_{j}\right) \lambda_{j}+\eta_{j}
$$

where the selection term $\lambda_{\mathrm{j}}$ is:

$$
\phi\left[H_{j}\left(\beta_{j}^{\prime} x_{i}\right)\right] / \Phi\left[H_{j}\left(\beta_{j}^{\prime} x_{i}\right)\right]
$$

The functions $\phi$ and $\Phi$ are the pdf and cdf of the standard normal distribution evaluated at the $\mathrm{P}(\mathrm{Y}=\mathrm{j} \mid \mathrm{x}) .{ }^{6}$ The vector $z_{t}$ includes human capital and labor market characteristics. The covariance and error terms are denoted by $\eta$ and $\rho \sigma$ respectively. Consistent estimates of $\alpha$ and $\rho \sigma$ are obtained

$$
{ }^{6} \mathrm{Or}, H_{j}\left(\beta_{j}^{\prime} x_{i}\right)=e^{\beta_{j}^{\prime} x_{i}} / 1+\sum_{k=0}^{4} e^{\beta_{k}^{\prime} x_{i}}
$$


through least squares regression of $\ln w_{i j}$ on $z_{i}$ and $\lambda_{\mathrm{j}}$.

\section{Data Set, Variables, and Hypotheses}

\section{Data set}

For the empirical analysis my data is drawn from the German Socioeconomic Panel (GSOEP), a nationally representative data set based on surveys conducted annually since 1984, and provided by the German Institute for Economic Research (DIW Berlin). I employ data from the latest release of the GSOEP (year 2002). This year is unique in that it includes detailed information on all populations living in Germany as it is enriched by additional refreshment samples. It also includes substantial information on labor force participation, self-employment categories, various aspects of life in Germany, and an assortment of attitudinal questions. More importantly, the 2002 data permit a more detailed analysis on the self-employed individuals. I can, thus, differentiate between those self-employed in agriculture, in the free-lance or professional sector, and in other self-employed categories including working for a family business (SOEP Group, 2002).

Out of the entire female population in Germany I create 5 nationality groups: (i) West German native women, (ii) East German native women, (iii) women from the European Union, including a few from the US, Canada, and Australia, (iv) women from the Eastern European countries, or the former Soviet block (Romanians, Yugoslavs, Albanians, Russians, etc), and (v) "other immigrant" women in Germany, that is women from all other nationalities (mostly from developing countries), including Turks (the largest immigrant group in Germany). The reference category is West German women.

The samples I select for the analysis exclude those individuals who are enrolled in school, are in the military, and in agriculture. I further confine the sample to those who provided valid answers to the relevant variables. Additionally, I restrict the analysis to individuals aged 
20 to 65 , a prime age range for paid- and self-employment endeavors. According to these selection criteria I end up with 2233 West Germans, 1453 East Germans, 372 European immigrants, 303 Eastern European immigrants, and 340 "other immigrants." For the wage regressions I consider only women with positive wages and hours of work. Because of the smaller sample size I grouped all non-European immigrants together. The final sample is reduced to 1210 West Germans, 808 East Germans, 182 European immigrants, and 255 nonEuropean immigrants.

\section{Variables and hypotheses}

Table 1 provides the rationale of the dependent variable in the occupational choice model. Categories 1 to 3 pertain to those women in the labor force, and include those registered as unemployed or on maternity leave. The last category is those not in the labor force. I distinguish between 4 distinct choices: (i) businesswomen in self-employment, (ii) businesswomen in the salaried sector, (iii) any other type of job in the salaried sector, and (iv) no employment.

A dummy for self-employment is constructed from a self-reported answer in the GSOEP questionnaire regarding the employment status of the individuals. It includes free-lance processionals, independent academics working in other business, and those working in family business. For all self-employed women, this is their main and only job. The businesswomen category includes employees with highly qualified and extensive managerial duties, and executive level jobs, such as head of departments, managers, managing directors, and heads of large firms. The other wage work category includes all other blue or white collar jobs. In the last category are those not in the labor force (housewives etc).

The explanatory variables used in this model include human capital variables (education, and health), variables that bear witness to socio-political attachments to Germany and general 
economic well-being (citizenship and home-ownership in Germany), intergenerational link variables (parents are self-employed), and control variables picking up family responsibilities and labor market availability (marital status, under-age children in the household).

For immigrants, I measure the effects of years of schooling and vocational training in the home country and years of schooling and vocational training in Germany separately. That way, I control for differences in the initial stock of human capital (education before migration) and render immigrants' education in Germany qualitatively similar to that of Germans and among themselves. I conjecture that the better educated will go into self-employment and business jobs. To the extent that education captures higher ability and allows individuals to know more and to have a superior information set, I expect that more years of schooling will push individuals into self-employment and upper managerial business jobs. More important is entrepreneurial talent, which often cannot be taught. Here, I only measure formal training. Abilities may be correlated with measured human capital, and the relationship with self-employment can be clouded in practice due to measurement problems. For example, people who have no formal degrees but do have entrepreneurial abilities are more likely to be self-employed.

In Germany, I would expect a strong positive correlation between education and selfemployment because there are required educational levels and qualifications, especially for certain occupations. However, it has been often argued that self-employment is an alternative job choice for less qualified and less skilled individuals. Self-employment could be, for example, a choice for women who want to combine work with family. It could, thus, very well be linked to unmeasured talents and not necessarily to high educational degrees. Health is also a vital element of human capital. I create the variable poor health based on a self-reported answer. I hypothesize that disability and self-employment are most likely negatively correlated.

To capture family background and any intergenerational transfers, I create a dummy 
variable for the parents being self-employed. Self-employed parents, besides providing life-experiences and know-how to their children, can also provide free on-the-job training. Moreover, self-employed parents may be able to financially support their children's start-up business and properly guide them in their decision. Lastly, children of self-employed parents are more likely to inherit the family business and go straight into self-employment. I hypothesize a positive relationship between the probability of choosing self-employment and the parents being self-employed.

The key variable for immigrant assimilation is the years-since-migration (YSM) variable. This variable measures the length of exposure to the German environment. It measures labor market experience and human capital accumulated in Germany. For those immigrants who are born in Germany, YSM is zero. In principle, labor force participation should increase with additional YSM for all occupations. I expect that the probability of being self-employed increases with additional YSM, albeit at a decreasing rate. The longer immigrants are in Germany the more they know the system and what they want to do, and the more likely they are to make the right occupational choice. ${ }^{7}$ Besides, with additional YSM, immigrants can overcome institutional hurdles such as acquiring residence permits and other certificates.

While older workers are more risk averse, in general, Blanchflower et al. (2001) find that the incidence of self-employment is higher for older workers and creates stronger feelings of job satisfaction. I expect that self-employment proclivity will increase with age, discounting for non-linearities. The rationale is that older workers have more wisdom, more experience and know-how, more financial capital, larger social milieu, and they make more prudent choices. The variable "own dwelling" is included as proxy for the individual's wealth. I expect that wealth will increase the probability of self-employment because it lessens the liquidity constraints (Taylor, 1996; Evans and Leighton, 1989). Home-ownership and wealth

\footnotetext{
${ }^{7}$ I acknowledge, however, that from this cross section I cannot disentangle any cohort effects and there may be a bias in the results.
} 
accumulation might, however, reduce the probability of working in lower ranked occupations. Self-employment can be a very attractive choice for married women with under-age children because it can offer flexibility in the allocation of time between family and work. I hypothesize that these variable will have a positive impact on self-employment proclivity. By the same token, these variables may have a negative impact on the proclivity to become a businesswoman in the wage sector. Immigrants who are German citizens may also choose selfemployment as a means of becoming successful, putting down roots, and having a business to hand down to their children. Similarly, citizenship gives the opportunity to access upper managerial jobs in companies and the government. Lastly, I expect to find wide variation in employment proclivities among the 5 nationality groups.

Following the human capital thesis I include the following variables in the wage regression: (i) pre- and post-migration years of schooling and vocational training, (ii) health, (iii) YSM and age, (iv) citizenship, and (v) marital status. I augment the model with labor market wage determinants such as: (i) working in the public sector, (ii) working in a small or average size company, and (iii) length of time in the business or firm. Lastly, I control for nationality differences and selection biases. According to the literature, I expect the following results.

In principle, wages increase with age and YSM at a decreasing rate. Wages are also higher for workers who have better health and are German citizens. For women specifically, I conjecture that being married is penalized in the labor market. Working in jobs in the public sector pays less because the public sector offers other amenities such as job security, strongly enforced labor union contracts, and less discrimination. Women working in small or average size firms should also earn less than women working in large firms. Longevity in the business (if one is self-employed) and in a company (if one is in paid-employment) should be rewarded in the labor market. I expect higher wages for women who have been in business longer. 
Lastly, I anticipate significant wage differences among the different nationalities. The sign and significance of the selection term $\lambda$ is a priori ambiguous. A significant $\lambda$ would indicate that the sample of these women workers is not a random sample of the population, and thus, adjustment is justified. A positive (negative) $\lambda$ would suggest that this non-random sample of workers is drawn from the upper (lower) part of the wage distribution.

\section{The characteristics of businesswomen in Germany}

In this section, I present an overview of selected characteristics of the 5 groups of women in Germany and make comparisons among them and across their employment types. Table 2 highlights the differences and similarities in that respect. On average, all women in the sample are in their late 30 s to early 40 s. West German native women are the oldest, while women in the "other immigrant" group are the youngest. Across all samples, a substantial proportion of women are married (over $60 \%$ ), while the share is highest for the "other immigrant" group of women $(81 \%)$ and lowest for East German women (61\%). While women in the "other immigrant" group have the highest percentage of under-age kids (62\%), East German women have the lowest percentage of under-age kids in the household (35\%) than any other group.

Overall, self-employment rates are low for all groups. West German women have the highest self-employment rate (5\%), followed by East German women (4\%) and immigrant women from the EU (4\%). Immigrant women from the former Soviet block countries have the lowest self-employment rates $(1 \%)$. The businesswomen category is dominated by the East Germans with $8 \%$, followed by West Germans with $7 \%$, while all immigrant women are lagging behind. Women in the "other immigrant" group rank the lowest in this career path with only $1 \%$. The latter also rank at the bottom for work in other jobs in the wage sector and at the top for not working; about half of the women in the rest of the nationalities are working in other jobs. West German women have the lowest percentage of no employment (39\%) and women 
in the "other immigrant" group have the highest (66\%). It is interesting that East German women in 2002 have almost the same labor force participation and no employment rates. This is in contrast to all previous statistics showing the East German women had a lot higher labor force participation than West German women.

Among all immigrant women, the eastern European immigrant women have the highest fraction of naturalization. It is interesting that while $16 \%$ of the women in the "other immigrant" group are born in Germany, only 4\% have become German citizens. Immigrant women from the EU have been in Germany for 19 years, on average, followed by the "other immigrants" (including Turks) who have been in Germany for 17 years. The average immigrant woman from the former Eastern block countries has been in Germany for 15 years. These numbers indicate a rather permanent migration, although citizenship rates are not high. The next rows of Table 2 indicate that these women express a positive attitude towards Germany, feeling integrated and wanting to stay in Germany. On a self-reported answer, $75 \%$ of the women from the former eastern block and $68 \%$ of the women from the "other immigrant" group said that they want to stay in Germany. Consistently, these women also report that they do not feel "at home" when they go back to their countries of origin.

Turning to their years of formal schooling and vocational/professional training, Table 2 shows that the eastern European immigrant women stand out with the highest years of premigration education (6 years). With regards to formal schooling and vocational/professional training acquired in Germany, East German women are the best educated group having finished, on average, some kind of college. They are followed by West German women having finished, on average, high school. Among the immigrant women, the Europeans seem to invest the most in post-migration education in Germany with 7 years of schooling.

Migrants still predominantly cluster in the West German territory and avoid the lessdeveloped East which has higher unemployment rates and lower wages. With respect to wealth 
and economic independence, $56 \%$ of the West German women are home-owners, followed by an impressive $43 \%$ by East German women (given that 10 years ago they were under a socialist regime). Looking at attitudinal variables concerning worries about their financial plight and job security, Table 2 provides evidence that West German women have the least worries among all groups. This can be explained by the traditional breadwinner German regime whereby German women marry well and rely on their husbands' income for security, who in turn are faring the best in the labor market. While it is understandable that the immigrant women worry the most about their financial situation (they are married to low income men in often precarious jobs) it is interesting that a high percentage of East German women also have such worries. In fact, they have the highest share of worry about job security, which is quite alarming.

Table 3 illustrates substantial disparities in the labor market among the female workers in the 5 nationality groups. Among all the women in the self-employment category, the European immigrants have the highest wages at 23.32Euros an hour. West German women rank second but with a big gap (12.40Euros an hour). Close behind are the East German women with 11.66Euros an hour. When I look closer at the wages of this group cross-tabulated with their geographic location, I find that the few self-employed East German women who live in the West earn a lot more than those who live in the East and even more than the West German women (17.54 versus 11.01 and 12.40 respectively). Their lower average wages may, thus, be due to the geographic location since the new German states have not fully adjusted to the wages of the states in the West. Still, the wages of the self-employed women in the "other immigrant" group are the lowest at 10.62Euros an hour.

Among all self-employed East German women work the most hours per week (44.83). In fact, it is the East German women in the east who work the longest hours (46.18 hours per week) and pull up the mean. East German women in the west work substantially less (32.73 hours per week) and seem to have adjusted to the shorter working week of the West. European 
immigrant women exhibit the highest longevity in business, having a company twice or three times as long as the other nationalities (with an average of 15 years of time in their company). The majority of these self-employed women, especially the East German women, are in smallscale business with less than 9 employees.

While all women in self-employment are over 40 years old, on average, the European immigrants are the oldest (49). Clearly, the East German women stand out with the highest levels of education, although the non-European immigrants also have high levels of education if one adds up the pre- and post-migration years. On the antipode are the European immigrants with only 4 years of education in Germany. However, they make up for it with their high premigration education.

All nationalities in the businesswomen category fare well. European immigrants earn more but the gap with the other nationalities is not as big as in the self-employment case. They also work longer hours than other nationalities (10 hours more than West German women and 15 hours more than the non-European immigrants) and all work in an average or large size firm. East German women have the longest tenure with the firm are older and have the most years of education than any other nationality in this employment type. However, it is interesting that all women in this category have high levels of education, even the immigrants.

In the other wage work category, it is the West German women who earn the highest wages, but they are closely followed by the other nationalities. They also have the longest tenure with the firm and are older on average than the other women workers. The East German women stand out again with their high work hours per week and years of education. Except for the European immigrants, the majority of these women work in an average to large size firm.

In sum, what emerges from Tables 2 and 3 on the raw characteristics is that there are significant differences across the nationalities and employment categories. Specifically, businesswomen in Germany fare the best; they have the highest years of education, work more 
hours, and earn the highest wages than any other employment category. Self-employed women rank second, earning more than women in the other wage work category but they are also older than women in the other employment categories. Overall, while European immigrants earn the highest wages, it is the East German women who work the most hours and have the most years of education.

\section{Estimation results}

\section{Multinomial logit results on occupational choices}

In Tables 4 and 5 I present the coefficients and standard errors of the multinomial logit regression estimation results. ${ }^{8}$ The asterisk denotes a $5 \%$ significance level in a 2 -tailed test. I present the results on the following 6 outcomes on the log-odds of: (i) self-employment versus a business career in paid-employment, (ii) self-employment versus another job in the wage sector, (iii) self-employment versus no employment, (iv) a business career in paid-employment versus other jobs in the wage sector, (v) a business career in paid-employment versus no employment, and (vi) another job in the wage sector versus no employment.

Table 4 presents the results on a parsimonious pure human capital model and Table 5 on the augmented model. In general, there are similarities between the outcomes in both models. With the exception of outcome (i), age is a positive and significant determinant for all outcomes in the human capital model. The odds of choosing self-employment or a business career in paid-employment versus other another job in the wage sector are high for younger women and low for older women, meaning that during their prime, women would rather choose a job with high remuneration. The odds of working (whether in self-employment, business, or other wage work) versus not working at all increase with age at a decreasing rate. The opposite pattern holds for outcome (i) in the augmented model. Controlling for all other covariates, the

\footnotetext{
${ }^{8}$ In Tables A1 and A2 in the appendix I present the corresponding marginal effects.
} 
odds of choosing self-employment versus business are lower when women are young and higher when women are older. This indicates that women in their prime would rather choose the high paying job in the "secure" sector. As predicted, self-employment becomes a more viable option later in life.

Understandably, the pattern of occupational choices with respect to YSM for both models is that with more YSM immigrant women are more likely to work and become selfemployed. Specifically, immigrant women are less likely to choose to be wage workers, selfemployed businesswomen, or businesswomen in paid-employment when they have few YSM, and they are more likely to do so when they accumulate more years in Germany. Unanimously, across all outcomes (i-vi) in both models, I find education in Germany to be a significant determinant. Except in outcome (i), the odds of working in any type of job versus not working as well as the odds of choosing the self-employment or business route versus the other wage work are higher for the more educated women. However, when the choice is between selfemployment and a business career in the salaried sector, the odds decrease with higher education indicating that the better educated women would rather choose paid-employment. Put differently, less educated women will choose self-employment. In fact, each additional year of education in Germany decreases the odds of choosing self-employment by 0.006 times in model 1 and 0.007 times in model 2.

Overall, pre-migration education is also a positive and significant determinant of outcomes (ii) to (v) meaning that immigrant women who arrive with higher education in Germany are more likely to choose self-employment or business when the alternative is a simple job in the wage sector or no work at all. However, pre-migration education is negative for outcome (i). This means that the more educated immigrant women are in their home countries, the less likely they are to venture into self-employment when they move to Germany. When I control for other characteristics in Table 5, however, the significant effect disappears. 
When the coefficient on poor health is significant it is also negative, implying that poor health is a deterrent to working in Germany. Women who have health problems (in both models) will choose not to work.

As expected, when the parents are self-employed, the odds of choosing self-employment are significantly higher but only for outcome (i). In fact, having self-employed parents increases the odds of choosing self-employment over a business career in the salaried sector by 0.007 times. While this shows a positive intergenerational spillover, it does not apply to outcomes (ii) and (iii).

For the choices (iii), (v), and (vi) I find that married women are less likely to work, whether it is in self-employment, business career in a company, or other wage work. It is interesting that women who have under-age kids in the household are significantly more likely to choose self-employment versus a business career or other wage work. This verifies the hypothesis that self-employment is an attractive option for parents who want to work and take care of their children as well. On the other hand, having small kids is a deterrent to choosing other types of employment, even self-employment, when the alternative is to not work. Clearly, in Germany, family responsibilities keep women away from the labor force.

Home-ownership is a positive and significant determinant of outcomes (ii), (iii), (iv), and (v). That is, women who own their dwelling in Germany are more likely to choose selfemployment when the alternative is another paid job or no employment by 0.01 times. Homeowners are also more likely to choose a business career versus another paid job or no work by 0.006 times. Women who live in the West are significantly more likely to choose a business career versus another job in the wage sector or even versus not working. They are also more likely to work in any job than not to work at all.

Holding everything else constant, results on the nationality variables show that women in the "other immigrant" group are less likely to work than work in the salaried sector as 
businesswomen or as plain employees compared to West German women. Along the same vein, East German women are less likely to choose self-employment over another job in the wage sector or over not working compared to West German women. These results suggest that East German women are perhaps less entrepreneurial than West German women, or they are discouraged because the institutional settings in the East are not conducive to entrepreneurship. Furthermore, East German women are less likely to choose a business career over a simple job in the wage sector compared to West German women. This is rather surprising because East German women have higher education levels and work more hours on average.

In sum, results on the occupational choices from Table 5 convey the following points: (i) self-employment choices are very sensitive to the alternative choice that women consider, (ii) women with under-age children clearly choose self-employment over other types of employment, but choose not to work when this option is available suggesting strong family considerations.

\section{Results on the wages of employed women}

I present the results on the wage regressions, both unadjusted and adjusted for selection, in Table 6. I report the coefficients, standard errors and significance level at 5\% in a two-tailed test. The unadjusted results (Column 1) pertain to all women in all employment types pooled together. In this exercise I control for self-employment or business career, in reference to a job in the wage sector. Column (1) shows that wages increase with age at a decreasing rate as expected. Wages also increase with each additional year of pre- and post-migration education by 3 and $4 \%$ respectively. Poor health, however, is penalized in the German labor market, whereby women suffer an $8 \%$ loss in wages. Unlike results for men, I find that married women experience a wage loss of 5\%, compared to single, divorced or widowed women.

Labor market characteristics show that while women who work in the public sector 
enjoy a $7 \%$ premium over those in the private sector, women who work in an average or small size firm suffer a wage loss of 14 to $35 \%$ respectively (compared to women who work in a large firm). Tenure and longevity with the company is rewarded albeit at a very low rate (1\%). Compared to West German women (the reference group), European immigrants earn $11 \%$ more but East German women earn 23\% less. Self-employed businesswomen and businesswomen in paid-employment earn 34 and 27\% more, respectively, than women in other jobs in the wage sector. This verifies that self-employment can be a lucrative profession.

Next, I discuss the hourly wage results adjusted for selection according to the 3 types of employment; that is, wages after women are selected into a certain occupation. Judging from the standard deviation of wages, self-employed businesswomen have the highest dispersion and businesswomen in the salaried sector have the smallest. Overall, across all types of employment, the wages of working women increase with age at a decreasing rate as predicted by the theory. In Figure 1, I plot the log-wage-age profiles of women in these 3 types of employment, evaluated at the mean of all other covariates. This Figure illustrates different paths to success according to employment type.

Clearly, businesswomen in paid-employment fare the best. They start with higher wages (higher intercept term), and earn more than women in the other types of employment throughout their working lives. Their profile lies entirely above that of the self-employed and dependent employed, showing that women in the other types of employment can never reach them. The wages of businesswomen in the salaried sector follow a steep upward profile but peak later in life, at the age of 52 (compared to the other profiles). However, their wages do not decrease as fast after that.

The log-wage-age profile of the self-employed women is more concave than the other 2 profiles and lies above that of the women in other dependent employment jobs. Although selfemployed women start at lower wages than women in the other paid jobs when they are young, 
they crossover at the age of 29 and increase faster after. Calculating the maximum wages with respect to age, I find that businesswomen in self-employed reach a maximum at 44 years of age. Their wages decrease quite rapidly thereafter, and in fact, they decrease below the wages of women in the simple jobs after the age of 59. This probably indicates that monetary success through self-employment is short-lived for women in Germany. Women in other dependent employment are depicted by the lowest and flattest curve. Their wages increase slower and decrease slower than the wages of businesswomen. While they reach a maximum at 47 years of age their wages stay within a narrow margin.

Regarding the rest of wage determinants, I find that self-employed businesswomen (Column 2) earn 7\% more with each additional year of education in Germany, suggesting that once women are sorted into self-employment education does matter. However, even selfemployed women are penalized when they are married, earning $24 \%$ less than non-married women. Controlling for everything else and adjusting for selection into employment, there are not significant wage differences by nationality. The exception is East German women, who earn $39 \%$ less than West German women (the reference group).

Businesswomen in paid-employment (Column 3) earn less when they have health problems, and the penalty is quite high $(14 \%)$. They also earn less when they work in an average or small size firm as opposed to working in a large firm. Women in small size firms are particularly penalized by earning $36 \%$ less. Tenure with the firm is only rewarded by $1 \%$. While I cannot confirm that immigrant women are different than West German women, consistently, I find that East German women earn significantly less than West German women. Although in this employment type East German women manage to narrow the wage gap with West German women, they still earn $17 \%$ less. Surprisingly, education is not a significant determinant of wages once businesswomen have selected themselves into that career path.

Women working in other jobs in the wage sector (Column 4) earn 3\% more for each 
additional year of pre-migration education and $4 \%$ more for each additional year of postmigration education. Poor health is once again penalized in the paid-employment sector. While women who work in the public sector enjoy a premium of $9 \%$, they pay a stiff penalty for not working in a large firm. The largest gap is between working in a small versus a large firm, where the former leads to $34 \%$ less earnings. Length of time with the company matters in a positive way. For each additional year a woman is with the same company her wages increase by $1 \%$. European immigrants perform well earning $8 \%$ more than West German women (the reference category) but only in the other jobs in the salaried sector. East German women, however, still earn 23\% less than West German women.

\section{Summary and concluding remarks}

In this paper I focus on businesswomen in Germany. I characterize businesswomen as women who exhibit entrepreneurship either through owning their own business or through working in another business in the salaried sector. I also study women in other types of dependent employment, and use women out of the labor force as the reference group. I address the following research questions: (i) what does it take to become a businesswoman? Are businesswomen in self-employment different than businesswomen in paid-employment in observed characteristics? (ii) is self-employment a clear choice over other jobs in the wage sector? And is it a preferred route to express their entrepreneurial talents, a quest to earn higher wages, to avoid possible discrimination in the wage sector, or to combine family with work in a more flexible setting? (iii) is self-employment a desperate choice out of unemployment or idleness? (iv) are some nationalities more entrepreneurial than others? (v) are women workers in these 3 types of employment a random sample? And (vi) how do they fare in the German labor market?

Based on the latest release of the GSOEP, I find that self-employed businesswomen are 
older, have adequate education, and earn more than women in other jobs in the wage sector. Among them, East German women work the longest hours per week but it is immigrants from the EU who have the highest wages. Businesswomen in paid-employment, as a group, earn the highest wages but they also work longer hours and have more years of education than women in the other 2 types of employment. Immigrant women in this group earn more than native women.

Conducting multinomial logit analysis on 6 pairs of occupational choices, I find that entrepreneurship proclivity is very sensitive to the alternative option. Overall, this analysis shows that women in Germany are more likely to choose a business career in paid-employment than in self-employment when they are in their prime working age, when they are educated, healthy, and home-owners. Likewise, women are more likely to choose another type of paidemployment over self-employment when are in their prime working age, well educated, and home-owners. Familial responsibilities clearly emerge as deterrents to a demanding business career. Self-employment is the preferred choice of younger educated women without children only when the alternative is no employment. Intergenerational occupational transmission is not as strong for women as other studies have shown it to be for men. When parents are selfemployed, this increases the proclivity to choose self-employment but only when the alternative is a business career in a company.

As a whole these results cannot confirm the hypothesis that self-employment is a means of taking advantage of the opportunities of the labor market and achieve a higher socio-economic standing. Self-employment is rather a way of escaping the unemployment lines and circumventing the conflict between family responsibilities and work obligations. While self-employment could be viewed as a 'rebellion' choice over other forms of simple paidemployment or no employment earlier in life, it is a conscious 'dream' choice later in life when women are free from family obligations and have acquired enough experience and financial 
capital. Having under-age children in the household increase the probability of being selfemployed, indicating that compared to other types of employment self-employment offers the desirable and valuable element of time and space flexibility.

East German women appear to be more risk averse than West German women, choosing a less demanding dependent job or no job at all rather than work as businesswomen. Raw statistics show that they worry more than all other women about job security. However, it is not clear whether other factors play a role in their decision. For example, it is possible that East Germany does not have, yet, the business infrastructure to accommodate and reward business opportunities. It is also possible that after growing up under a socialistic regime, East German women do not appreciate, yet, the value of a business career. Moreover, it could be that they do not have enough self-confidence or that they are not ready yet to deal with the exigencies of a fast-pace job of a businesswoman. Immigrant women in the "other immigrant" group are more likely not to work than to work in paid-employment. This indicates that women in this group are not integrated in the German labor market; when they, actually, have a choice to be integrated they would rather stay unemployed and idle.

As a whole, businesswomen in paid-employment earn the highest wages throughout their working lives. However, self-employment also offers women workers a successful and lucrative alternative. While higher education is rewarded in self-employment it is irrelevant for businesswomen in paid-employment. Consistently and invariably, I find that East German women earn less than West German women in all types of employment. 


\section{REFERENCES}

Amemiya, T. (1985). Advanced Econometrics, Harvard University Press, Cambridge, Massachusetts.

Arastirmalar, T. and Vakfi, M. (2003). Die Wirtschaftskraft der türkischen Selbständigen, Essen: Stiftung Zentrum für Türkeistudien.

Audretsch, D. B. (2002). Entrepreneurship: A Survey of the Literature, paper prepared for the European Commission, Enterprise Directorate General, mimeo.

Audretsch, D. B., Thurik, R., Verheul, I. and Wennekers, S. (2002). Entrepreneurship: Determinants and Policy in a European-U.S. Comparison, Boston: Kluwer Academic Publishers.

Blanchflower, D. G., Oswald, A. and Stutzer, A. (2001). 'Latent Entrepreneurship Across Nations', European Economic Review, Vol. 45, pp. 680-691.

Borjas, G. J. (1986). 'The Self-Employment Experience of Immigrants,' Journal of Human Resources, Vol. 21, No. 4, pp. 485-506.

Clark, K. and Drinkwater, S. (1998). 'Ethnicity and Self-employment in Britain', Oxford Bulletin of Economics and Statistics, Vol. 60, No. 3, pp. 383-407.

Constant, A. (1998). 'The Earnings of Male and Female Guestworkers and Their Assimilation into the German Labor Market: A Panel Study 1984-1993', Ph.D. Dissertation: Vanderbilt University.

Constant, A. and Schultz-Nielsen, M.L. (2004). 'Immigrant Self-employment and Economic Performance', in Migrants, Work, and the Welfare State, Tranæs, T. and. Zimmermann, K. F., editors. University Press of Southern Denmark: Odense.

Constant, A. and Shachmurove, Y. (2003). 'Entrepreneurial Ventures and Wage Differentials between Germans and Immigrants', IZA DP No. 879, Bonn.

Constant, Amelie, Shachmurove, Yochanan, and Zimmermann, Klaus F. (2003), 'What Makes an Entrepreneur and Does It Pay? Native Men, Turks, and Other Migrants in Germany', IZA Discussion Paper No. 940, Bonn.

Evans, D. S. and Leighton, L. S. (1989). 'Some Empirical Aspects of Entrepreneurship,' American Economic Review, Vol. 79, No. 3, pp. 519-535.

Fairlie, R. W. and Meyer, B. D. (1996). 'Ethnic and Racial Self-employment Differences and Possible Explanations', Journal of Human Resources, Vol. 31, No. 4, pp. 757-793.

Fehrenbach, S. And Lauxen-Ulbrich, M. (2002). 'A Gender View on Self-Employment in Germany', Institute for Small Business Research DP No. 4, Mannheim.

Georgellis, Y. And Wall, H. J. (2000). 'Gender Differences in Self-Employment: Panel 
Evidence from the former West Germany', FED of St. Louis WP No. 1999-008B, St. Louis.

Hükum, P. and Le Saout, D. (2002). 'Les femmes Migrantes et la Création d' Activité', Migrations Etudes, No. 104.

IOM. (2003) Managing Migration Challenges and Responses for People on the Move, Vol. 2, Geneva.

Jungbauer-Gans and Preisendörfer, P. (1992). 'Frauen in der beruflichen Selbständigkeit', Zeitschrift für Soziologie, Heft 1.

Kanein, W. (1988). Ausländerrecht, Beck: München.

Le, A. T. (1999). 'Empirical Studies of Self-Employment', Journal of Economic Surveys, Vol. 13, No. 4, pp. 381-416.

Lee, L. (1983). 'Generalized Econometric Models with Selectivity', Econometrica, Vol. 51, pp. 507-512.

Lofstrom, M. (2002). 'Labor Market Assimilation and the Self-employment Decision of Immigrant Entrepreneurs', Journal of Population Economics, Vol. 15, pp. 83-114.

Lohmann, H. (2001). 'Self-employed or Employee, Full-time or Part-time? Gender Differences in the determinants and Conditions for Self-employment in Europe and the US', MZES DP No. 38, Mannheim.

McFadden, D. (1973). 'Conditional Logit Analysis of Qualitative Choice Behavior', in Frontiers of econometrics, Zarembka, P., editor. New York: Academic Press, pp. 105142.

McManus, P.A. (2001). 'Occupational Choice and Career Experiences', Vierteljahrshefte zuer Wirtschaftsforschung, Vol. 70, pp. 24-30.

OECD (2000). Small and Medium Enterprise Outlook

Pfeiffer, F. and Reize, F. (2000). 'Business Start-ups by the Unemployed - an Econometric Analysis Based on Firm Data', Labour Economics, Vol. 7, pp. 629-663.

SOEP Group (2002). 'The German Socio-Economic Panel (GSOEP) after more than 15 years Overview', Quarterly Journal of Economic Research, Vol. 70, pp. 7-14.

Taylor, M. P. (1996). 'Earnings, Independence or Unemployment: Why Become SelfEmployed?', Oxford Bulletin of Economics and Statistics, Vol. 58, No. 3, pp. 253-266.

Taylor, M. P. (2001). 'Self-Employment and Windfall Gains in Britain: Evidence from Panel Data', Economica, Vol. 68, pp. 539-565. 
TABLE 1

Occupational Categories

\begin{tabular}{lcl}
\hline Constructed Dependent Variable & GSOEP Contents \\
\hline Self-employed & $(0)$ & $\begin{array}{l}\text { Self-employed with or without employees; } \\
\text { includes free lance professionals, independent } \\
\text { academics, other business, and family } \\
\text { business }\end{array}$ \\
Businesswomen & $(1)$ & $\begin{array}{l}\text { Employees with highly qualified and } \\
\text { extensive managerial duties, executive level; } \\
\text { head of departments, managers, managing } \\
\text { directors, head of large firm } \\
\text { All other blue or white collar jobs }\end{array}$ \\
Other wage work & $(2)$ & \\
Not employed & $(3)$ & Housewives, etc \\
\end{tabular}


TABLE 2

Selected Characteristics of Women in Germany by Nationality*

\begin{tabular}{|c|c|c|c|c|c|}
\hline & $\begin{array}{c}\text { Native } \\
\text { West } \\
\text { Germans }\end{array}$ & $\begin{array}{l}\text { Native } \\
\text { East } \\
\text { Germans }\end{array}$ & $\begin{array}{l}\text { European } \\
\text { Immigrants }\end{array}$ & $\begin{array}{c}\text { Immigrants } \\
\text { from Former } \\
\text { Eastern } \\
\text { Block } \\
\end{array}$ & $\begin{array}{c}\text { Other } \\
\text { Immigrants } \\
\text { (incl. } \\
\text { Turks) } \\
\end{array}$ \\
\hline Age in years & 41.45 & 41.09 & 41.18 & 39.61 & 37.25 \\
\hline Married & 0.65 & 0.61 & 0.73 & 0.70 & 0.81 \\
\hline Single & 0.24 & 0.26 & 0.19 & 0.17 & 0.12 \\
\hline Kids under 16 in Household & 0.39 & 0.35 & 0.44 & 0.42 & 0.62 \\
\hline Self-Employed & 0.05 & 0.04 & 0.04 & 0.01 & 0.02 \\
\hline Businesswomen & 0.07 & 0.08 & 0.04 & 0.02 & 0.01 \\
\hline Other wage work & 0.50 & 0.49 & 0.49 & 0.51 & 0.32 \\
\hline Not Employed & 0.39 & 0.40 & 0.44 & 0.46 & 0.66 \\
\hline Naturalized Citizen & & & 0.04 & 0.20 & 0.03 \\
\hline Born in Germany & & & 0.00 & 0.14 & 0.16 \\
\hline Years since Migration $^{1}$ & & & 19.27 & 14.81 & 16.54 \\
\hline $\begin{array}{l}\text { Feel like Belonging to Home } \\
\text { Country }\end{array}$ & & & 0.23 & 0.16 & 0.14 \\
\hline Want to Stay in Germany & & & 0.55 & 0.75 & 0.68 \\
\hline $\begin{array}{l}\text { Years of Education in the } \\
\text { Home Country }\end{array}$ & & & 3.56 & 5.61 & 3.67 \\
\hline $\begin{array}{l}\text { Years of Education in } \\
\text { Germany }\end{array}$ & 11.74 & 13.82 & 7.07 & 5.12 & 5.38 \\
\hline Poor Health & 0.15 & 0.14 & 0.18 & 0.20 & 0.19 \\
\hline Parents Self-Employed & 0.13 & 0.06 & 0.07 & 0.05 & 0.08 \\
\hline Live in West Germany & 0.99 & 0.10 & 1.00 & 0.98 & 0.99 \\
\hline Own Dwelling in Germany & 0.56 & 0.43 & 0.38 & 0.21 & 0.21 \\
\hline Financial Worries & 0.15 & 0.28 & 0.20 & 0.30 & 0.38 \\
\hline Worries about Job Security & 0.05 & 0.11 & 0.06 & 0.09 & 0.05 \\
\hline Worries about Immigration & 0.27 & 0.30 & 0.14 & 0.16 & 0.18 \\
\hline Number of Observations & 2233 & 1453 & 372 & 303 & 340 \\
\hline
\end{tabular}

Notes: * Numbers are in percent, and may not add up to 100 due to rounding

${ }^{1}$ Calculated for those who are not born in Germany

Source: Own calculations from GSOEP 2002 
TABLE 3

Labor Market and Human Capital Characteristics by Nationality and Occupational Status ${ }^{1}$

\begin{tabular}{|c|c|c|c|c|c|}
\hline & & $\begin{array}{c}\text { Native West } \\
\text { Germans }\end{array}$ & $\begin{array}{c}\text { Native East } \\
\text { Germans }\end{array}$ & $\begin{array}{c}\text { European } \\
\text { Immigrants }\end{array}$ & $\begin{array}{c}\text { Non-European } \\
\text { Immigrants }\end{array}$ \\
\hline \multirow{7}{*}{ Self-Employed } & Hourly wage in $€$ & 12.40 & 11.66 & 29.13 & 10.62 \\
\hline & Hours per week & 31.20 & 44.83 & 34.02 & 31.75 \\
\hline & Length of time in business & 7.28 & 7.04 & 15.44 & 3.20 \\
\hline & Work in small company & $76 \%$ & $85 \%$ & $70 \%$ & $50 \%$ \\
\hline & Age & 43.28 & 46.68 & 49.10 & 42.75 \\
\hline & $\begin{array}{l}\text { Years of education in } \\
\text { Germany }\end{array}$ & 12.51 & 15.49 & 3.70 & 8.25 \\
\hline & $\begin{array}{l}\text { Years of education in the } \\
\text { home country }\end{array}$ & & & 8.45 & 8.13 \\
\hline \multirow{7}{*}{ Businesswomen } & Hourly wage in $€$ & 17.19 & 15.42 & 22.29 & 18.19 \\
\hline & Hours per week & 37.84 & 42.47 & 46.61 & 31.21 \\
\hline & Length of time in business & 7.82 & 10.84 & 9.43 & 3.60 \\
\hline & Work in small company & $7 \%$ & $4 \%$ & $0 \%$ & $14 \%$ \\
\hline & Age & 39.27 & 42.72 & 39.92 & 40.86 \\
\hline & $\begin{array}{l}\text { Years of education in } \\
\text { Germany }\end{array}$ & 15.37 & 17.75 & 11.86 & 10.71 \\
\hline & $\begin{array}{l}\text { Years of education in the } \\
\text { home country }\end{array}$ & & & 5.42 & 6.29 \\
\hline \multirow{7}{*}{ Other wage work } & Hourly wage in $€$ & 11.82 & 9.71 & 11.35 & 9.91 \\
\hline & Hours per week & 29.76 & 36.28 & 30.68 & 29.50 \\
\hline & Length of time in business & 9.26 & 7.74 & 8.62 & 6.64 \\
\hline & Work in small company & $12 \%$ & $11 \%$ & $56 \%$ & $12 \%$ \\
\hline & Age & 40.61 & 39.33 & 39.98 & 38.74 \\
\hline & $\begin{array}{l}\text { Years of education in } \\
\text { Germany }\end{array}$ & 11.58 & 14.06 & 6.93 & 5.40 \\
\hline & $\begin{array}{l}\text { Years of education in the } \\
\text { home country }\end{array}$ & & & 3.27 & 4.76 \\
\hline \multicolumn{2}{|c|}{ Number of Observations } & 1210 & 808 & 182 & 255 \\
\hline
\end{tabular}

${ }^{1}$ Based on observations with positive wages
Source: Own calculations from GSOEP 2002 
TABLE 4

Human Capital Multinomial Logit Results

\begin{tabular}{|c|c|c|c|c|c|c|}
\hline \multirow{3}{*}{ Independent Variables } & \multicolumn{5}{|c|}{ Dependent Variable: Log Odds } & \multirow{3}{*}{$\begin{array}{c}\ln (O / N) \\
(6) \\
\end{array}$} \\
\hline & $\ln (S / B)$ & $\ln (S / O)$ & $\ln (S / N)$ & $\ln (B / O)$ & $\ln (B / N)$ & \\
\hline & (1) & (2) & (3) & (4) & (5) & \\
\hline Constant & $\begin{array}{l}3.205^{*} \\
(1.038)\end{array}$ & $\begin{array}{l}-8.136^{*} \\
(0.826)\end{array}$ & $\begin{array}{c}-15.134^{*} \\
(0.829)\end{array}$ & $\begin{array}{c}-11.341^{*} \\
(0.717)\end{array}$ & $\begin{array}{c}-18.339^{*} \\
(0.727)\end{array}$ & $\begin{array}{c}-6.998^{*} \\
(0.242)\end{array}$ \\
\hline Age & $\begin{array}{l}-0.054 \\
(0.047)\end{array}$ & $\begin{array}{l}0.139^{*} \\
(0.037)\end{array}$ & $\begin{array}{l}0.521 * \\
(0.037)\end{array}$ & $\begin{array}{l}0.193 * \\
(0.033)\end{array}$ & $\begin{array}{l}0.574 * \\
(0.033)\end{array}$ & $\begin{array}{l}0.381 * \\
(0.012)\end{array}$ \\
\hline $\mathrm{Age}^{2}$ & $\begin{array}{c}0.001 \\
(0.001)\end{array}$ & $\begin{array}{l}-0.001 * \\
(0.0004)\end{array}$ & $\begin{array}{l}-0.006^{*} \\
(0.0004)\end{array}$ & $\begin{array}{l}-0.002 * \\
(0.0004)\end{array}$ & $\begin{array}{l}-0.007 * \\
(0.0004)\end{array}$ & $\begin{array}{l}-0.005^{*} \\
(0.0001)\end{array}$ \\
\hline Years Since Migration & $\begin{array}{l}-0.036 \\
(0.043)\end{array}$ & $\begin{array}{l}-0.089 * \\
(0.033)\end{array}$ & $\begin{array}{l}-0.138 * \\
(0.033)\end{array}$ & $\begin{array}{l}-0.054 \\
(0.031)\end{array}$ & $\begin{array}{l}-0.102 * \\
(0.032)\end{array}$ & $\begin{array}{l}-0.049^{*} \\
(0.012)\end{array}$ \\
\hline Years Since Migration $^{2}$ & $\begin{array}{c}0.001 \\
(0.001)\end{array}$ & $\begin{array}{l}0.002 * \\
(0.001)\end{array}$ & $\begin{array}{l}0.003 * \\
(0.001)\end{array}$ & $\begin{array}{c}0.001 \\
(0.001)\end{array}$ & $\begin{array}{l}0.003 * \\
(0.001)\end{array}$ & $\begin{array}{c}0.001 * \\
(0.0003)\end{array}$ \\
\hline $\begin{array}{l}\text { Years of Education in the } \\
\text { Home Country }\end{array}$ & $\begin{array}{r}-0.090^{*} \\
(0.043)\end{array}$ & $\begin{array}{l}0.214^{*} \\
(0.032)\end{array}$ & $\begin{array}{l}0.237 * \\
(0.033)\end{array}$ & $\begin{array}{l}0.304^{*} \\
(0.034)\end{array}$ & $\begin{array}{l}0.327 * \\
(0.035)\end{array}$ & $\begin{array}{c}0.023 \\
(0.015)\end{array}$ \\
\hline $\begin{array}{l}\text { Years of Education in } \\
\text { Germany }\end{array}$ & $\begin{array}{l}-0.212 * \\
(0.018)\end{array}$ & $\begin{array}{l}0.162^{*} \\
(0.015)\end{array}$ & $\begin{array}{l}0.197 * \\
(0.016)\end{array}$ & $\begin{array}{l}0.374 * \\
(0.013)\end{array}$ & $\begin{array}{l}0.409^{*} \\
(0.014)\end{array}$ & $\begin{array}{l}0.035^{*} \\
(0.008)\end{array}$ \\
\hline Poor Health & $\begin{array}{c}0.075 \\
(0.204)\end{array}$ & $\begin{array}{l}-0.088 \\
(0.161)\end{array}$ & $\begin{array}{c}-0.678^{*} \\
(0.162)\end{array}$ & $\begin{array}{l}-0.163 \\
(0.150)\end{array}$ & $\begin{array}{c}-0.754^{*} \\
(0.152)\end{array}$ & $\begin{array}{c}-0.590^{*} \\
(0.068)\end{array}$ \\
\hline $\log L$ & & & & & & \\
\hline$\chi^{2}$ & & & & & & \\
\hline Number of Observations & & & & & & \\
\hline
\end{tabular}

Note: $\mathrm{S}=$ Self-Employment, $\mathrm{B}=$ Businesswoman, $\mathrm{O}=$ Other Wage Work, $\mathrm{N}=$ Not Employed

* indicates significance at the 5 per cent level in a two-tailed test $(\mathrm{p}<0.05)$

standard errors in parentheses

Source: Own calculations from GSOEP 2002 
TABLE 5

Multinomial Logit Results, Augmented Model

\begin{tabular}{|c|c|c|c|c|c|c|}
\hline \multirow[b]{2}{*}{ Independent Variables } & \multicolumn{5}{|c|}{ Dependent Variable: Log Odds } & \multirow[b]{2}{*}{$\begin{array}{c}\ln (O / N) \\
(6)\end{array}$} \\
\hline & $\begin{array}{c}\ln (S / B) \\
(1)\end{array}$ & $\begin{array}{c}\ln (S / O) \\
(2)\end{array}$ & $\begin{array}{c}\ln (S / N) \\
(3)\end{array}$ & $\begin{array}{c}\ln (B / O) \\
(4)\end{array}$ & $\begin{array}{c}\ln (B / N) \\
(5)\end{array}$ & \\
\hline Constant & $\begin{array}{l}5.298^{*} \\
(1.122)\end{array}$ & $\begin{array}{l}-7.738^{*} \\
(0.875)\end{array}$ & $\begin{array}{l}-16.362^{*} \\
(0.883)\end{array}$ & $\begin{array}{c}-13.037^{*} \\
(0.801)\end{array}$ & $\begin{array}{l}-21.661^{*} \\
(0.822)\end{array}$ & $\begin{array}{l}-8.624^{*} \\
(0.291)\end{array}$ \\
\hline Age & $\begin{array}{l}-0.176^{*} \\
(0.052)\end{array}$ & $\begin{array}{l}0.087^{*} \\
(0.040)\end{array}$ & $\begin{array}{l}0.609 * \\
(0.041)\end{array}$ & $\begin{array}{l}0.264 * \\
(0.037)\end{array}$ & $\begin{array}{l}0.785^{*} \\
(0.038)\end{array}$ & $\begin{array}{l}0.522^{*} \\
(0.015)\end{array}$ \\
\hline $\mathrm{Age}^{2}$ & $\begin{array}{l}0.002^{*} \\
(0.001)\end{array}$ & $\begin{array}{l}-0.0005 \\
(0.0005)\end{array}$ & $\begin{array}{l}-0.007^{*} \\
(0.0005)\end{array}$ & $\begin{array}{l}-0.003^{*} \\
(0.0004)\end{array}$ & $\begin{array}{l}-0.009^{*} \\
(0.0004)\end{array}$ & $\begin{array}{l}-0.006^{*} \\
(0.0002)\end{array}$ \\
\hline Years Since Migration & $\begin{array}{l}-0.043 \\
(0.049)\end{array}$ & $\begin{array}{l}-0.088^{*} \\
(0.036)\end{array}$ & $\begin{array}{l}-0.099^{*} \\
(0.036)\end{array}$ & $\begin{array}{l}-0.046 \\
(0.036)\end{array}$ & $\begin{array}{l}-0.057 \\
(0.037)\end{array}$ & $\begin{array}{l}-0.011 \\
(0.014)\end{array}$ \\
\hline Years Since Migration ${ }^{2}$ & $\begin{array}{l}0.0007 \\
(0.001)\end{array}$ & $\begin{array}{l}0.002 * \\
(0.001)\end{array}$ & $\begin{array}{l}0.002 * \\
(0.001)\end{array}$ & $\begin{array}{c}0.001 \\
(0.001)\end{array}$ & $\begin{array}{c}0.002 \\
(0.001)\end{array}$ & $\begin{array}{c}0.0003 \\
(0.0004)\end{array}$ \\
\hline $\begin{array}{l}\text { Years of Education in the } \\
\text { Home Country }\end{array}$ & $\begin{array}{l}-0.075 \\
(0.046)\end{array}$ & $\begin{array}{l}0.249^{*} \\
(0.035)\end{array}$ & $\begin{array}{l}0.259^{*} \\
(0.035)\end{array}$ & $\begin{array}{l}0.325^{*} \\
(0.035)\end{array}$ & $\begin{array}{l}0.335^{*} \\
(0.037)\end{array}$ & $\begin{array}{c}0.010 \\
(0.016)\end{array}$ \\
\hline $\begin{array}{l}\text { Years of Education in } \\
\text { Germany }\end{array}$ & $\begin{array}{l}-0.213^{*} \\
(0.019)\end{array}$ & $\begin{array}{l}0.179^{*} \\
(0.016)\end{array}$ & $\begin{array}{l}0.200^{*} \\
(0.016)\end{array}$ & $\begin{array}{l}0.392^{*} \\
(0.014)\end{array}$ & $\begin{array}{l}0.412^{*} \\
(0.015)\end{array}$ & $\begin{array}{l}0.020^{*} \\
(0.009)\end{array}$ \\
\hline Poor Health & $\begin{array}{c}0.106 \\
(0.205)\end{array}$ & $\begin{array}{l}0.0004 \\
(0.162)\end{array}$ & $\begin{array}{r}-0.716^{*} \\
(0.163)\end{array}$ & $\begin{array}{l}-0.106 \\
(0.151)\end{array}$ & $\begin{array}{l}-0.822 * \\
(0.154)\end{array}$ & $\begin{array}{r}-0.716^{*} \\
(0.071)\end{array}$ \\
\hline Self-Employed Parents & $\begin{array}{l}0.409^{*} \\
(0.205)\end{array}$ & $\begin{array}{c}0.200 \\
(0.159)\end{array}$ & $\begin{array}{l}0.135 \\
(0.164)\end{array}$ & $\begin{array}{l}-0.208 \\
(0.158)\end{array}$ & $\begin{array}{l}-0.273 \\
(0.166)\end{array}$ & $\begin{array}{l}-0.065 \\
(0.084)\end{array}$ \\
\hline Married & $\begin{array}{c}0.238 \\
(0.158)\end{array}$ & $\begin{array}{c}0.059 \\
(0.132)\end{array}$ & $\begin{array}{l}-0.329 * \\
(0.138)\end{array}$ & $\begin{array}{l}-0.179 \\
(0.110)\end{array}$ & $\begin{array}{l}-0.566^{*} \\
(0.119)\end{array}$ & $\begin{array}{l}-0.388^{*} \\
(0.066)\end{array}$ \\
\hline Kids under 16 in Household & $\begin{array}{l}0.596^{*} \\
(0.146)\end{array}$ & $\begin{array}{l}0.281^{*} \\
(0.121)\end{array}$ & $\begin{array}{c}-0.888^{*} \\
(0.127)\end{array}$ & $\begin{array}{l}-0.314 * \\
(0.104)\end{array}$ & $\begin{array}{r}-1.484^{*} \\
(0.112)\end{array}$ & $\begin{array}{l}-1.170^{*} \\
(0.062)\end{array}$ \\
\hline Own Dwelling in Germany & $\begin{array}{c}0.149 \\
(0.134)\end{array}$ & $\begin{array}{l}0.360^{*} \\
(0.111)\end{array}$ & $\begin{array}{l}0.366^{*} \\
(0.114)\end{array}$ & $\begin{array}{l}0.210^{*} \\
(0.094)\end{array}$ & $\begin{array}{l}0.217^{*} \\
(0.099)\end{array}$ & $\begin{array}{c}0.006 \\
(0.051)\end{array}$ \\
\hline Naturalized Citizen & $\begin{array}{l}-0.185 \\
(0.487)\end{array}$ & $\begin{array}{l}-0.462 \\
(0.382)\end{array}$ & $\begin{array}{l}-0.564 \\
(0.387)\end{array}$ & $\begin{array}{l}-0.277 \\
(0.342)\end{array}$ & $\begin{array}{l}-0.379 \\
(0.350)\end{array}$ & $\begin{array}{l}-0.102 \\
(0.135)\end{array}$ \\
\hline $\begin{array}{l}\text { Live in Former West German } \\
\text { Territory }\end{array}$ & $\begin{array}{l}-0.220 \\
(0.182)\end{array}$ & $\begin{array}{c}0.109 \\
(0.156)\end{array}$ & $\begin{array}{c}0.312 \\
(0.161)\end{array}$ & $\begin{array}{l}0.329^{*} \\
(0.127)\end{array}$ & $\begin{array}{l}0.532^{*} \\
(0.136)\end{array}$ & $\begin{array}{l}0.203^{*} \\
(0.081)\end{array}$ \\
\hline European Immigrant & $\begin{array}{c}0.406 \\
(0.481)\end{array}$ & $\begin{array}{c}0.233 \\
(0.357)\end{array}$ & $\begin{array}{l}0.135 \\
(0.364)\end{array}$ & $\begin{array}{l}-0.173 \\
(0.369)\end{array}$ & $\begin{array}{l}-0.271 \\
(0.380)\end{array}$ & $\begin{array}{l}-0.098 \\
(0.149)\end{array}$ \\
\hline $\begin{array}{l}\text { Immigrant from the former } \\
\text { Eastern Block }\end{array}$ & $\begin{array}{l}-0.899 \\
(0.775)\end{array}$ & $\begin{array}{l}-1.151 \\
(0.631)\end{array}$ & $\begin{array}{l}-1.213 \\
(0.636)\end{array}$ & $\begin{array}{l}-0.252 \\
(0.485)\end{array}$ & $\begin{array}{l}-0.314 \\
(0.493)\end{array}$ & $\begin{array}{l}-0.062 \\
(0.156)\end{array}$ \\
\hline Other Nationality Immigrant & $\begin{array}{c}0.948 \\
(0.790)\end{array}$ & $\begin{array}{c}0.375 \\
(0.494)\end{array}$ & $\begin{array}{l}-0.382 \\
(0.494)\end{array}$ & $\begin{array}{l}-0.573 \\
(0.658)\end{array}$ & $\begin{array}{l}-1.330^{*} \\
(0.661)\end{array}$ & $\begin{array}{c}-0.757^{*} \\
(0.159)\end{array}$ \\
\hline Native East German & $\begin{array}{l}-0.138 \\
(0.226)\end{array}$ & $\begin{array}{l}-0.489^{*} \\
(0.195)\end{array}$ & $\begin{array}{l}-0.406^{*} \\
(0.202)\end{array}$ & $\begin{array}{c}-0.351^{*} \\
(0.150)\end{array}$ & $\begin{array}{l}-0.268 \\
(0.161)\end{array}$ & $\begin{array}{c}0.083 \\
(0.093)\end{array}$ \\
\hline $\log \mathrm{L}$ & & & & & & \\
\hline$\chi^{2}$ & & & & & & \\
\hline Number of Observations & & & & & & \\
\hline
\end{tabular}

Note: $\mathrm{S}=$ Self-Employment, $\mathrm{B}=$ Businesswoman, $\mathrm{O}=$ Other Wage Work, $\mathrm{N}=$ Not Employed

$*$ indicates significance at the 5 per cent level in a two-tailed test $(\mathrm{p}<0.05)$

standard errors in parentheses

Source: Own calculations from GSOEP 2002 
TABLE 6

Wage regressions

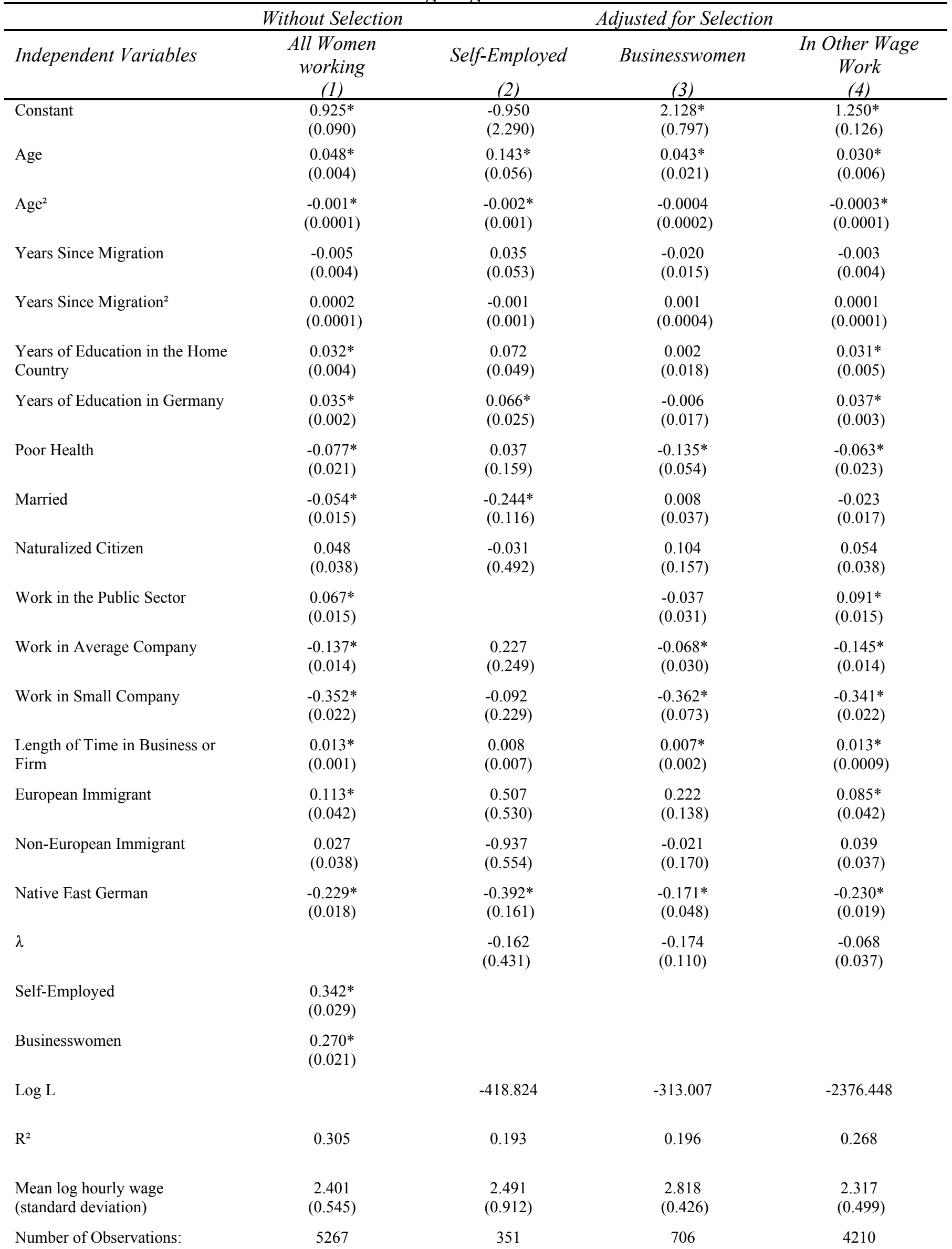

Note: $*$ indicates significance at the 5 per cent level in a two-tailed test $(\mathrm{p}<0.05)$

Standard errors in parentheses

Source: Own calculations from GSOEP 2002 


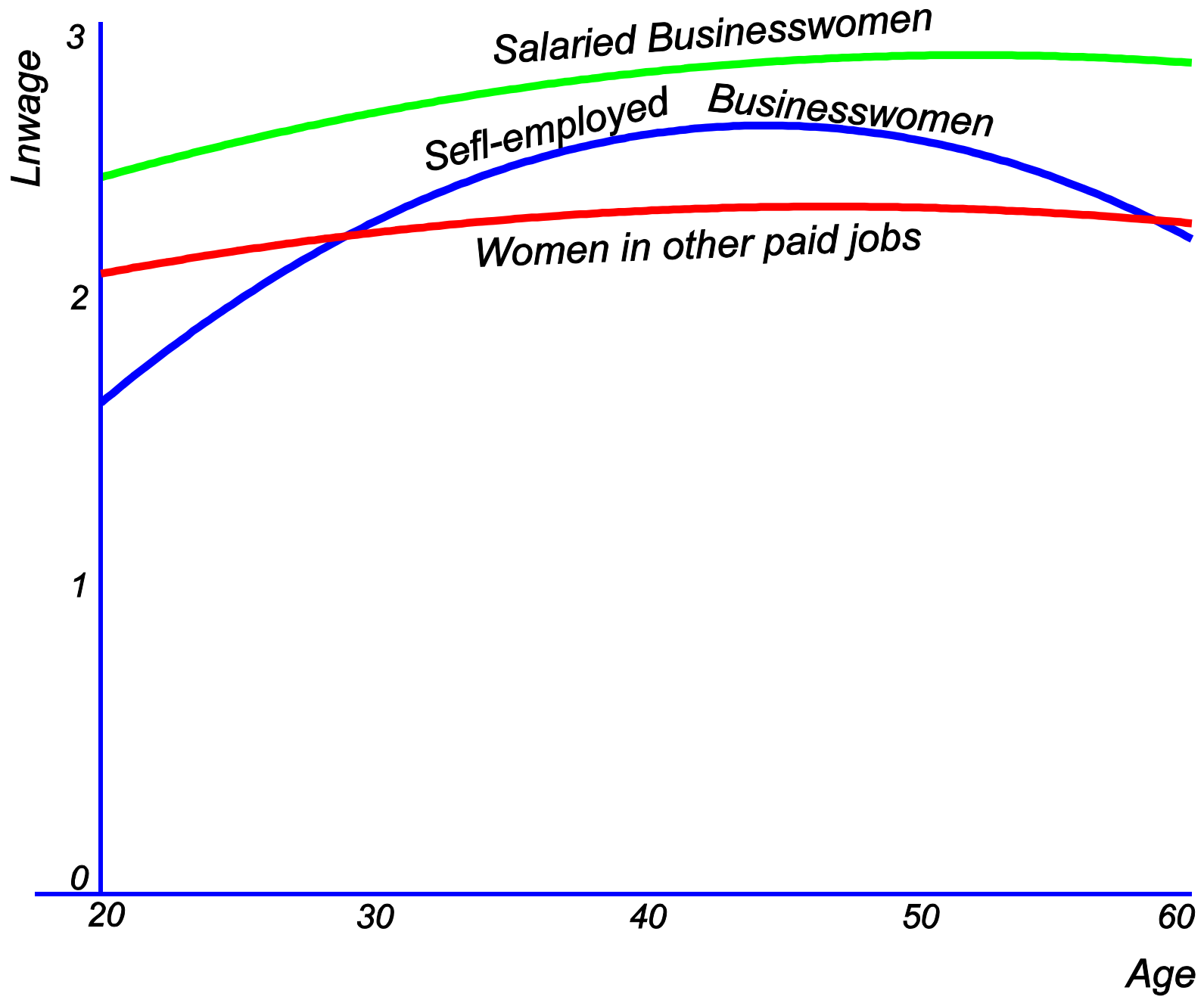

Figure 1: Women's wage-age profiles by occupational path 
Appendix

TABLE A1

Human Capital Multinomial Logit Marginal Effects

\begin{tabular}{|c|c|c|c|c|c|c|}
\hline \multirow[b]{2}{*}{ Independent Variables } & \multicolumn{6}{|c|}{ Dependent Variable: Log Odds } \\
\hline & $\begin{array}{c}\ln (S / B) \\
(1)\end{array}$ & $\begin{array}{c}\ln (S / O) \\
(2)\end{array}$ & $\begin{array}{c}\ln (S / N) \\
(3)\end{array}$ & $\begin{array}{c}\ln (B / O) \\
(4)\end{array}$ & $\begin{array}{c}\ln (B / N) \\
(5)\end{array}$ & $\begin{array}{c}\ln (\mathrm{O} / \mathrm{N}) \\
(6)\end{array}$ \\
\hline Constant & $\begin{array}{l}-0.405^{*} \\
(0.024)\end{array}$ & $\begin{array}{l}-0.405^{*} \\
(0.024)\end{array}$ & $\begin{array}{l}-0.405^{*} \\
(0.024)\end{array}$ & $\begin{array}{l}-0.463^{*} \\
(0.024)\end{array}$ & $\begin{array}{l}-0.463^{*} \\
(0.024)\end{array}$ & $\begin{array}{l}-1.105^{*} \\
(0.059)\end{array}$ \\
\hline Age & $\begin{array}{l}0.011^{*} \\
(0.001)\end{array}$ & $\begin{array}{l}0.011^{*} \\
(0.001)\end{array}$ & $\begin{array}{l}0.011^{*} \\
(0.001)\end{array}$ & $\begin{array}{l}0.012^{*} \\
(0.001)\end{array}$ & $\begin{array}{l}0.012^{*} \\
(0.001)\end{array}$ & $\begin{array}{l}0.074^{*} \\
(0.003)\end{array}$ \\
\hline $\mathrm{Age}^{2}$ & $\begin{array}{l}-0.0001^{*} \\
(0.00001)\end{array}$ & $\begin{array}{l}-0.0001 * \\
(0.00001)\end{array}$ & $\begin{array}{l}-0.0001^{*} \\
(0.00001)\end{array}$ & $\begin{array}{l}-0.0001 * \\
(0.00001)\end{array}$ & $\begin{array}{l}-0.0001^{*} \\
(0.00001)\end{array}$ & $\begin{array}{l}-0.0009^{*} \\
(0.00003)\end{array}$ \\
\hline Years Since Migration & $\begin{array}{l}-0.004 * \\
(0.001)\end{array}$ & $\begin{array}{c}-0.004 * \\
(0.001)\end{array}$ & $\begin{array}{c}-0.004 * \\
(0.001)\end{array}$ & $\begin{array}{l}-0.002 * \\
(0.001)\end{array}$ & $\begin{array}{l}-0.002 * \\
(0.001)\end{array}$ & $\begin{array}{l}-0.007 * \\
(0.003)\end{array}$ \\
\hline Years Since Migration ${ }^{2}$ & $\begin{array}{l}0.0001 * \\
(0.00003)\end{array}$ & $\begin{array}{l}0.0001 * \\
(0.00003)\end{array}$ & $\begin{array}{c}0.0001 * \\
(0.00003)\end{array}$ & $\begin{array}{c}0.0001^{*} \\
(0.00003)\end{array}$ & $\begin{array}{l}0.0001^{*} \\
(0.00003)\end{array}$ & $\begin{array}{l}0.0002 * \\
(0.0001)\end{array}$ \\
\hline $\begin{array}{l}\text { Years of Education in the } \\
\text { Home Country }\end{array}$ & $\begin{array}{l}0.008^{*} \\
(0.001)\end{array}$ & $\begin{array}{l}0.008^{*} \\
(0.001)\end{array}$ & $\begin{array}{l}0.008^{*} \\
(0.001)\end{array}$ & $\begin{array}{l}0.010^{*} \\
(0.001)\end{array}$ & $\begin{array}{l}0.010^{*} \\
(0.001)\end{array}$ & $\begin{array}{l}-0.005 \\
(0.003)\end{array}$ \\
\hline $\begin{array}{l}\text { Years of Education in } \\
\text { Germany }\end{array}$ & $\begin{array}{l}0.006^{*} \\
(0.001)\end{array}$ & $\begin{array}{l}0.006^{*} \\
(0.001)\end{array}$ & $\begin{array}{l}0.006^{*} \\
(0.001)\end{array}$ & $\begin{array}{l}0.013 * \\
(0.001)\end{array}$ & $\begin{array}{l}0.013^{*} \\
(0.001)\end{array}$ & $\begin{array}{l}-0.003 \\
(0.002)\end{array}$ \\
\hline Poor Health & $\begin{array}{l}-0.013^{*} \\
(0.006)\end{array}$ & $\begin{array}{l}-0.013^{*} \\
(0.006)\end{array}$ & $\begin{array}{l}-0.013^{*} \\
(0.006)\end{array}$ & $\begin{array}{l}-0.014^{*} \\
(0.005)\end{array}$ & $\begin{array}{c}-0.014^{*} \\
(0.005)\end{array}$ & $\begin{array}{c}-0.120^{*} \\
(0.016)\end{array}$ \\
\hline $\log \mathrm{L}$ & \multicolumn{6}{|c|}{-9004.782} \\
\hline$\chi^{2}$ & \multicolumn{6}{|c|}{3155.471} \\
\hline Number of Observations & \multicolumn{6}{|c|}{9972} \\
\hline
\end{tabular}

Note: $\mathrm{S}=$ Self-Employment, $\mathrm{B}=$ Businesswoman, $\mathrm{O}=$ Other Wage Work, $\mathrm{N}=$ Not Employed

* indicates significance at the 5 per cent level in a two-tailed test $(\mathrm{p}<0.05)$

standard errors in parentheses

Source: Own calculations from GSOEP 2002 
TABLE A2

Multinomial Logit Marginal Effects, Augmented Model

\begin{tabular}{|c|c|c|c|c|c|c|}
\hline \multirow[b]{2}{*}{ Independent Variables } & \multicolumn{5}{|c|}{ Dependent Variable: Log Odds } & \multirow[b]{2}{*}{$\begin{array}{c}\ln (O / N) \\
(6)\end{array}$} \\
\hline & $\begin{array}{c}\ln (S / B) \\
(1)\end{array}$ & $\begin{array}{c}\ln (S / O) \\
(2)\end{array}$ & $\begin{array}{c}\ln (S / N) \\
(3)\end{array}$ & $\begin{array}{c}\ln (B / O) \\
(4)\end{array}$ & $\begin{array}{c}\ln (B / N) \\
(5)\end{array}$ & \\
\hline Constant & $\begin{array}{l}-0.411^{*} \\
(0.027)\end{array}$ & $\begin{array}{l}-0.411^{*} \\
(0.027)\end{array}$ & $\begin{array}{l}-0.411^{*} \\
(0.027)\end{array}$ & $\begin{array}{l}-0.490^{*} \\
(0.026)\end{array}$ & $\begin{array}{l}-0.490^{*} \\
(0.026)\end{array}$ & $\begin{array}{l}-1.455^{*} \\
(0.070)\end{array}$ \\
\hline Age & $\begin{array}{l}0.011^{*} \\
(0.001)\end{array}$ & $\begin{array}{l}0.011^{*} \\
(0.001)\end{array}$ & $\begin{array}{l}0.011^{*} \\
(0.001)\end{array}$ & $\begin{array}{l}0.014^{*} \\
(0.001)\end{array}$ & $\begin{array}{l}0.014^{*} \\
(0.001)\end{array}$ & $\begin{array}{l}0.104^{*} \\
(0.004)\end{array}$ \\
\hline $\mathrm{Age}^{2}$ & $\begin{array}{l}-0.0001^{*} \\
(0.00001)\end{array}$ & $\begin{array}{l}-0.0001^{*} \\
(0.00001)\end{array}$ & $\begin{array}{l}-0.0001^{*} \\
(0.00001)\end{array}$ & $\begin{array}{l}-0.0002^{*} \\
(0.00001)\end{array}$ & $\begin{array}{l}-0.0002 * \\
(0.00001)\end{array}$ & $\begin{array}{c}-0.001 * \\
(0.00004)\end{array}$ \\
\hline Years Since Migration & $\begin{array}{l}-0.003^{*} \\
(0.001)\end{array}$ & $\begin{array}{l}-0.003 * \\
(0.001)\end{array}$ & $\begin{array}{l}-0.003 * \\
(0.001)\end{array}$ & $\begin{array}{l}-0.001 \\
(0.001)\end{array}$ & $\begin{array}{l}-0.001 \\
(0.001)\end{array}$ & $\begin{array}{l}0.0002 \\
(0.003)\end{array}$ \\
\hline Years Since Migration $^{2}$ & $\begin{array}{c}0.0001 * \\
(0.00003)\end{array}$ & $\begin{array}{c}0.0001 * \\
(0.00003)\end{array}$ & $\begin{array}{c}0.0001^{*} \\
(0.00003)\end{array}$ & $\begin{array}{c}0.00004 \\
(0.00003)\end{array}$ & $\begin{array}{c}0.00004 \\
(0.00003)\end{array}$ & $\begin{array}{l}0.00001 \\
(0.0001)\end{array}$ \\
\hline $\begin{array}{l}\text { Years of Education in the } \\
\text { Home Country }\end{array}$ & $\begin{array}{l}0.009^{*} \\
(0.001)\end{array}$ & $\begin{array}{l}0.009^{*} \\
(0.001)\end{array}$ & $\begin{array}{l}0.009^{*} \\
(0.001)\end{array}$ & $\begin{array}{l}0.010^{*} \\
(0.001)\end{array}$ & $\begin{array}{l}0.010^{*} \\
(0.001)\end{array}$ & $\begin{array}{l}-0.008^{*} \\
(0.004)\end{array}$ \\
\hline $\begin{array}{l}\text { Years of Education in } \\
\text { Germany }\end{array}$ & $\begin{array}{l}0.007^{*} \\
(0.001)\end{array}$ & $\begin{array}{l}0.007^{*} \\
(0.001)\end{array}$ & $\begin{array}{l}0.007 * \\
(0.001)\end{array}$ & $\begin{array}{l}0.012^{*} \\
(0.001)\end{array}$ & $\begin{array}{l}0.012^{*} \\
(0.001)\end{array}$ & $\begin{array}{l}-0.006^{*} \\
(0.002)\end{array}$ \\
\hline Poor Health & $\begin{array}{l}-0.011 \\
(0.006)\end{array}$ & $\begin{array}{l}-0.011 \\
(0.006)\end{array}$ & $\begin{array}{l}-0.011 \\
(0.006)\end{array}$ & $\begin{array}{r}-0.012 * \\
(0.004)\end{array}$ & $\begin{array}{l}-0.012 * \\
(0.004)\end{array}$ & $\begin{array}{l}-0.150^{*} \\
(0.017)\end{array}$ \\
\hline Self-Employed Parents & $\begin{array}{c}0.007 \\
(0.006)\end{array}$ & $\begin{array}{c}0.007 \\
(0.006)\end{array}$ & $\begin{array}{c}0.007 \\
(0.006)\end{array}$ & $\begin{array}{l}-0.007 \\
(0.005)\end{array}$ & $\begin{array}{l}-0.007 \\
(0.005)\end{array}$ & $\begin{array}{l}-0.015 \\
(0.020)\end{array}$ \\
\hline Married & $\begin{array}{l}-0.004 \\
(0.005)\end{array}$ & $\begin{array}{l}-0.004 \\
(0.005)\end{array}$ & $\begin{array}{l}-0.004 \\
(0.005)\end{array}$ & $\begin{array}{l}-0.010^{*} \\
(0.003)\end{array}$ & $\begin{array}{l}-0.010^{*} \\
(0.003)\end{array}$ & $\begin{array}{l}-0.081^{*} \\
(0.015)\end{array}$ \\
\hline Kids under 16 in Household & $\begin{array}{l}-0.007 \\
(0.004)\end{array}$ & $\begin{array}{l}-0.007 \\
(0.004)\end{array}$ & $\begin{array}{l}-0.007 \\
(0.004)\end{array}$ & $\begin{array}{l}-0.024^{*} \\
(0.003)\end{array}$ & $\begin{array}{l}-0.024^{*} \\
(0.003)\end{array}$ & $\begin{array}{l}-0.249^{*} \\
(0.014)\end{array}$ \\
\hline Own Dwelling in Germany & $\begin{array}{l}0.013^{*} \\
(0.004)\end{array}$ & $\begin{array}{l}0.013^{*} \\
(0.004)\end{array}$ & $\begin{array}{l}0.013^{*} \\
(0.004)\end{array}$ & $\begin{array}{l}0.006^{*} \\
(0.003)\end{array}$ & $\begin{array}{l}0.006^{*} \\
(0.003)\end{array}$ & $\begin{array}{c}-0.010 \\
(0.012)\end{array}$ \\
\hline Naturalized Citizen & $\begin{array}{l}-0.019 \\
(0.014)\end{array}$ & $\begin{array}{l}-0.019 \\
(0.014)\end{array}$ & $\begin{array}{l}-0.019 \\
(0.014)\end{array}$ & $\begin{array}{l}-0.009 \\
(0.010\end{array}$ & $\begin{array}{l}-0.009 \\
(0.010\end{array}$ & $\begin{array}{c}0.007 \\
(0.032)\end{array}$ \\
\hline $\begin{array}{l}\text { Live in Former West German } \\
\text { Territory }\end{array}$ & $\begin{array}{c}0.007 \\
(0.006)\end{array}$ & $\begin{array}{c}0.007 \\
(0.006)\end{array}$ & $\begin{array}{c}0.007 \\
(0.006)\end{array}$ & $\begin{array}{l}0.012^{*} \\
(0.004)\end{array}$ & $\begin{array}{l}0.012^{*} \\
(0.004)\end{array}$ & $\begin{array}{c}0.035 \\
(0.019)\end{array}$ \\
\hline European Immigrant & $\begin{array}{c}0.007 \\
(0.013)\end{array}$ & $\begin{array}{c}0.007 \\
(0.013)\end{array}$ & $\begin{array}{c}0.007 \\
(0.013)\end{array}$ & $\begin{array}{l}-0.007 \\
(0.011)\end{array}$ & $\begin{array}{l}-0.007 \\
(0.011)\end{array}$ & $\begin{array}{l}-0.023 \\
(0.035)\end{array}$ \\
\hline East European Immigrant & $\begin{array}{l}-0.044 \\
(0.023)\end{array}$ & $\begin{array}{l}-0.044 \\
(0.023)\end{array}$ & $\begin{array}{l}-0.044 \\
(0.023)\end{array}$ & $\begin{array}{l}-0.007 \\
(0.014)\end{array}$ & $\begin{array}{l}-0.007 \\
(0.014)\end{array}$ & $\begin{array}{c}0.015 \\
(0.038)\end{array}$ \\
\hline Other Nationality Immigrant & $\begin{array}{c}0.003 \\
(0.018)\end{array}$ & $\begin{array}{c}0.003 \\
(0.018)\end{array}$ & $\begin{array}{c}0.003 \\
(0.018)\end{array}$ & $\begin{array}{l}-0.027 \\
(0.019)\end{array}$ & $\begin{array}{l}-0.027 \\
(0.019)\end{array}$ & $\begin{array}{l}-0.159^{*} \\
(0.040)\end{array}$ \\
\hline Native East German & $\begin{array}{l}-0.017 * \\
(0.007)\end{array}$ & $\begin{array}{l}-0.017 * \\
(0.007)\end{array}$ & $\begin{array}{l}-0.017^{*} \\
(0.007)\end{array}$ & $\begin{array}{l}-0.009 * \\
(0.004)\end{array}$ & $\begin{array}{c}-0.009 * \\
(0.004)\end{array}$ & 0.033 \\
\hline $\log \mathrm{L}$ & & & -86 & 406 & & \\
\hline$\chi^{2}$ & & & & & & \\
\hline $\begin{array}{l}\text { Number of } \\
\text { Observations }\end{array}$ & & & & & & \\
\hline
\end{tabular}

Note: $\mathrm{S}=$ Self-Employment, $\mathrm{B}=$ Businesswoman, $\mathrm{O}=$ Other Wage Work, $\mathrm{N}=$ Not Employed

* indicates significance at the 5 per cent level in a two-tailed test $(\mathrm{p}<0.05)$

standard errors in parentheses

Source: Own calculations from GSOEP 2002 